This item was submitted to Loughborough's Research Repository by the author.

Items in Figshare are protected by copyright, with all rights reserved, unless otherwise indicated.

\title{
Central heating thermostat settings and timing: building demographics
}

PLEASE CITE THE PUBLISHED VERSION

http://dx.doi.org/10.1080/09613210903263007

PUBLISHER

(c) Taylor \& Francis

VERSION

AM (Accepted Manuscript)

LICENCE

CC BY-NC-ND 4.0

REPOSITORY RECORD

Shipworth, Michelle, Steven K. Firth, Michael I. Gentry, A.J. Wright, David T. Shipworth, and Kevin J. Lomas. 2019. "Central Heating Thermostat Settings and Timing: Building Demographics". figshare.

https://hdl.handle.net/2134/11586. 
This item was submitted to Loughborough's Institutional Repository (https://dspace.lboro.ac.uk/) by the author and is made available under the following Creative Commons Licence conditions.

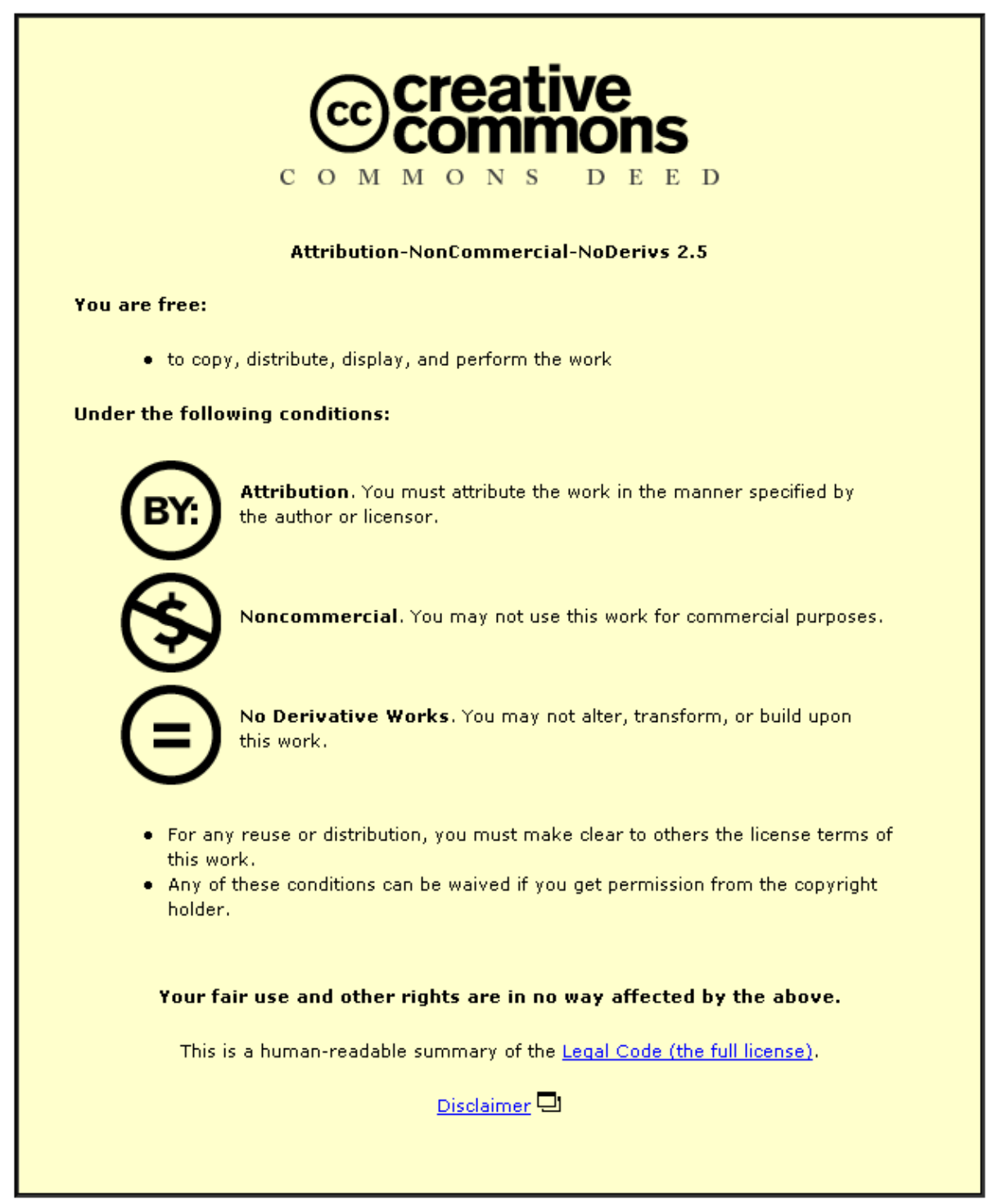

For the full text of this licence, please go to: http://creativecommons.org/licenses/by-nc-nd/2.5/ 


\title{
Central heating thermostat settings and timing: building demographics
}

\author{
Author's Accepted Manuscript for:
}

Shipworth, M. ${ }^{1}$, Firth, S. K. ${ }^{2}$, Gentry, M. I. ${ }^{3}$, Wright, A. J. ${ }^{4}$, Shipworth, D. T. ${ }^{5}$ and Lomas, K. J. $^{6}$ (2010) Central heating thermostat settings and timing: building demographics, Building Research \& Information, 38(1), 50-69.

Available from: http://dx.doi.org/10.1080/09613210903263007.

Shipworth, Michelle (corresponding author)m.shipworth@ucl.ac.uk

UCL Energy Institute, University College London

Firth, Steven K. S.K.Firth@1boro.ac.uk

Department of Civil and Building Engineering, Loughborough University

Gentry, Michael I. mig.gentry@gmail.com

Wright, Andrew J. AWright@dmu.ac.uk

Institute of Energy and Sustainable Development, De Montfort University

Shipworth, David T.d.shipworth@ucl.ac.uk

UCL Energy Institute, University College London

Lomas, Kevin J. K.J.Lomas@lboro.ac.uk

Department of Civil and Building Engineering, Loughborough University 


\section{Abstract}

Crucial empirical data (currently absent in building energy models) on central heating demand temperatures and durations are presented. This data is derived from the first national survey of energy use in English homes and includes monitored temperatures in living rooms, central heating settings reported by participants, along with building, technical and behavioural data. The results are compared to model assumptions with respect to thermostat settings and heating durations. Contrary to assumptions, the use of controls did not reduce average maximum living room temperatures or duration of operation. Regulations, policies and programs may need to revise their assumptions that adding controls will reduce energy use. Alternative forms of heating control should be developed and tested to ascertain whether their use saves energy in real-world settings. Given the finding that detached houses are heated for longer, these dwellings should be particularly targeted in energy efficiency retrofit programs. Furthermore, social marketing programs could use the wide variation in thermostat settings as the foundation of a 'social norm' program aimed at reducing temperatures in 'overheated' homes. Finally, building energy models that inform energy policies require firmer foundations in real world data to improve policy effectiveness. Greater coordination of data collection and management would make more data available for this purpose.

\section{Keywords}

building energy model, central heating, control systems, demand temperature, domestic heating controls, energy demand, inhabitant behaviour, thermostat setting 


\section{Introduction}

\section{The use of central heating}

Use of residential central heating accounts for about $1 / 8^{\text {th }}$ of UK carbon emissions. Policies and programs are urgently required to reduce the carbon emissions associated with its use, but that use is very poorly understood. Nearly $90 \%$ of homes are centrally heated (Communities and Local Government 2007), space heating accounts for 53\% of residential carbon emissions (DEFRA 2006) and households account for around 27\% of UK emissions (DEFRA 2006).

The UK government is committed, under the Kyoto Protocol, to reducing 2012 greenhouse gas emissions to $12.5 \%$ below 1990 levels (DEFRA, 2008a). The government has also set the domestic target of reducing emissions to 20\% below 1990 levels by 2010 (DEFRA, 2008a). The recently enacted Climate Change Act 2008 commits the government to a legally binding target of reducing UK carbon dioxide (CO2) emissions in 2050 to $80 \%$ below those in 1990 (DEFRA, 2008b). The Act's interim target of reducing emissions by $26 \%$ by 2020 was subsequently tightened to $34 \%$ by statute (Office of Public Sector Information (OPSI), 2008).

These targets are likely to require large emission reductions from UK dwellings, especially since reductions in this sector are considered relatively low cost (CCC 2008). Any policies and initiatives aimed at significantly reducing residential $\mathrm{CO}_{2}$ emissions must address the largest residential $\mathrm{CO}_{2}$ emitter - central heating. And, to be effective, these policies and initiatives must be informed by sound evidence of how central heating is used.

Key determinants of a home's space heating energy use (and thus $\mathrm{CO}_{2}$ emissions) are heating demand temperatures (thermostat settings where thermostats are used) and heating duration. 
This is demonstrated in a parallel paper in this special issue journal in which Firth et al. carry out a sensitivity analysis of an energy and carbon model of the English housing stock. They find heating demand temperatures have the greatest influence; a $1 \%$ rise in heating demand temperatures is estimated to cause a $1.55 \%$ rise in $\mathrm{CO}_{2}$ emissions. Heating duration has the second greatest influence and a $1 \%$ rise in the number of heating hours is estimated to result in a $0.62 \%$ rise in $\mathrm{CO}_{2}$ emissions. The third most influential variable is external air temperature which is also a key determinant of space heating. Building fabric and extent of heating are other important influences on space heating energy use.

\section{The need for data}

Despite the significance of heating demand temperatures and durations, the main models used to inform residential energy and carbon reduction policy-making in the UK are based on the same core building energy model - BREDEM (the Building Research Establishment's Domestic Energy Model) - which uses assumed heating demand temperatures and heating durations. BREDEM version 8 assumes that the living room is heated to $21^{\circ} \mathrm{C}-$ for nine hours on weekdays ( $7 \mathrm{am}$ to $9 \mathrm{am}$ and $4 \mathrm{pm}$ to $11 \mathrm{pm}$ ) and for 16 hours on weekends ( $7 \mathrm{am}$ to 11pm) (Anderson et. al. 2002).

The UK Government's method for the energy rating of dwellings uses the default heating regime as given in BREDEM (BRE 2005a). This method - the Standard Assessment Procedure (SAP) - is used both as a regulatory instrument (forming part of the building regulations) and as a predictive tool (predicting the likely effect of energy efficiency interventions). 
Three prominent housing stock models use BREDEM as their core building energy model: the UK Domestic Carbon Model (Boardman, 2007), the model developed by Johnston et al. (2005) and the DECarb model (Natarajan and Levermore 2007). None provide evidence of using anything other than BREDEM's default heating demand temperature and duration. The Building Research Establishment's UK housing stock model, BREHOMES, uses different thermostat settings, initially based on spot measurements obtained during the English House Condition Survey, but 'fine-tuned' during the model validation process (Shorrock and Dunster 1997). There is no evidence that BREHOMES uses heating durations that differ from the BREDEM default values. All of these housing stock models are used in scenario planning to develop effective $\mathrm{CO}_{2}$ reduction policies.

There is currently little alternative to using BREDEM's default heating demand temperatures and durations, because there have not been the comprehensive studies which could provide the necessary data for the models:

'The UK has had a world lead in such computer modelling through the development of Building Research Establishment Domestic Energy Model (BREDEM) and subsequently the Standard Assessment Procedure (SAP) in the domestic sector...However there is a real dearth of hard data with which to validate these models and take account statistically of variations in occupant behaviour... This difficulty in getting real data has produced an over reliance on theoretical predictions'

(Oreszczyn and Lowe 2004).

The lack of data on heating demand temperatures and durations undermines the credibility of recommendations generated in predictive policy making and scenario planning processes. 
The UK's new Department of Energy \& Climate Change recently claimed that fitting boiler controls and thermostatic valves to radiators had a potential impact of $1.5 \mathrm{MtCO}_{2}$ per year (DECC 2009 p. 32). Their only reference for this claim was Enviros Consulting (2008, p 66), who say:

"If the ten million homes that do not currently have modern 'standard' controls (room thermostat, electronic programmer and thermostatic radiator valves) are given them they could save around 1.5MtC."

The figure of ten million homes without modern 'standard' controls they derive from an interview with The Association of Controls Manufacturers. The same interview references, but does not cite, work done in Europe for the Energy Using Products Directive, which apparently found a gas saving of 10-30\% if all three elements of a modern standard heating control system are installed. Enviros also note that the Energy Savings Trust estimates that adding 'standard' controls saves about $£ 92$ a year in fuel bills. Finally, they cite King’s Lynn $\&$ West Norfolk Council (2008), which claims that heating controls will save as much as 17\% on the average heating bill. However, the council document does not indicate where their figures come from. Clearly, policy-makers are struggling to find the data they need on central heating systems controls.

The UK's Energy Saving Trust (2008) claims that 'fitting the correct heating controls (timer, room thermostat and thermostatic radiator valves) could typically save you around $17 \%$ of your heating bill', but they do not cite evidence for this. In 2005, the UK government's Market Transformation Programme claimed that getting householders to use heating controls properly was one of the most promising actions for further reductions in home energy consumption. They claimed that householders 'ignoring or abusing [sic] existing heating controls' wasted about 14TWh of energy a year (Market Transformation Programme 2005 p. 
36). However, by 2006, the Market Transformation Programme emphasised instead that policy makers need:

'field data collected from a large and representative sample of households...[to] show how [central heating] systems and controls are used in order to provide the necessary inputs for energy modelling of the effect of controls'

(2006, p. 11).

In particular they want to know what temperature people heat dwellings to with and without temperature control, and the duration of heating with and without time control.

DEFRA (2008c) believe their target to reduce energy use from conventional domestic heating and hot water systems by $3.5 \%$ by 2020 can be achieved at reasonable cost through three main measures, the foremost of which is that $75 \%$ of the homes that have the heating controls specified by the building regulations (timer, thermostat and thermostatic radiator valves) set and use the controls correctly by 2013 . However, they recognise that:

"the relationship between the performance of products measured under test conditions and what is achieved in real life, could lead to reduced effectiveness of the policy programme".

Policy makers need high quality data on the use of central heating system controls.

There have only been a limited number of studies which purposefully attempt to measure thermostat settings and central heating durations, and most of these are out-dated. One of the most significant studies was in 1978 - spot measurements of internal temperatures in 1,000 UK dwellings (Hunt and Gidman 1982). A 1984 study of 171 houses in the South Eastern Gas Board region included spot temperature measurements and reported thermostat settings 
and hours of use of central heating (Griffiths 1987). However, there are no reports or publications of the temperature findings. Furthermore that study could not be used to generalise results to England or the UK as it was only of owner-occupied centrally heated houses in just one English region. In 1996 the English House Condition Survey carried out spot temperature measurements on a national sample of English homes (DETR 2000). Spot measurements provide the temperature of the home at a single moment in time and as such act only a guide to thermostat settings. Recent, periodic temperature data from loggers is available only for non-representative samples of dwellings. Martin and Watson (2006) report on a study of 59 homes which received insulation upgrades in which the heating patterns used in the households are calculated from temperature loggers placed on the heating system itself. Oreszczyn et al.'s (2006) study of 1,600 low-income recipients of the Warm Front energy efficiency grant scheme included half-hourly temperature logger data. However, these recent studies do not provide nationally representative data on thermostat settings and heating patterns which could be used for policy development. Furthermore interdisciplinary surveys of home energy use are extremely rare, despite recognition for over twenty years (e.g. Vine 1986, Hitchcock 1993) that advances in this field require the integration of building, technical, social and behavioural measures into home energy use surveys.

This paper provides crucial empirical data that building energy models currently lack - that on central heating demand temperatures and durations, derived from the first national survey of energy use in English homes. This survey includes building, technical, socio-demographics and behavioural measures. The results are compared to model assumptions with respect to thermostat settings and heating durations to ascertain whether any assumptions appear to be incorrect, because incorrect assumptions could mislead policy makers. 


\section{Method}

\section{Survey overview and sampling of participants}

In winter early in 2007 in England, the Carbon Reduction in Buildings (CaRB) project commenced this survey of home energy use, having been granted permission to proceed by the University of Reading Ethics Committee. During the computer assisted 45-minute face-toface interviews, householders answered structured questions on their home's built form, heating technologies, heating practices and socio-demographics. The use of open questions would have allowed participants to provide 'other' reasons for their behaviour not covered in our structured questions. However, when using open questions, researchers cannot infer that a specific 'other' reason does not apply to a given participant simply because that participant did not mention that specific 'other' reason. This means that participants' 'other' responses cannot meaningfully be compared, limiting the usefulness of open questions in studies using statistics. During the interviews householders were asked if they would accommodate two temperature sensors for a year - one in the main living room and one in the main bedroom.

Households were selected by stratified random sample drawn from the Postcode Address File for England. To ensure a good geographic and socio-demographic spread, postcode sectors were stratified by Government Office Region and socio-economic class ${ }^{\text {ii }} .54$ postcode sectors were selected at random in proportion to the number of addresses they covered and 21 addresses were sampled in each selected postcode sector. Out of 1134 addresses, 427 households were interviewed - a response rate of $44 \%$. Sampling and the face-to-face interviews were conducted on our behalf by the National Centre for Social Research NatCen. NatCen found the low response rates were due to householders' concerns that 
interviewers were working either for the government as 'environmental 'spies', or for energy utilities as salespeople. The geographical distribution of the sample is illustrated in Figure 1.

Figure 1 Map of local authorities sampled in the survey

This paper explores the practices of the CaRB subsample using gas or oil fired central heating systems with radiators as their main form of heating. They comprise $84 \%$ of the CaRB sample -358 households. The reason for focusing on this subsample is twofold. Firstly, the building regulations energy efficiency rating system, the Standard Assessment Procedure (SAP) assigns the same assumptions with respect to living room temperatures for all of these systems (BRE 2008). Secondly, these systems "are installed in $83 \%$ of the housing stock, and account for $52 \%$ of CO2 emissions from the domestic sector" (DEFRA 2008c p. 2).

\section{Temperature measurements, estimated thermostat settings and}

\section{hours active}

Monitoring central heating system settings directly on the 427 study homes would have been prohibitively expensive, so this study estimated the settings from temperature data recorded in the study homes.

Internal temperatures were measured using Hobo UA-001-08 temperature sensors which are small (about the size of a matchbox), silent and, once installed, unobtrusive. Correct sensor placement would be best achieved by a trained technician placing the sensors and asking householders not to move them. However, it would then be extremely expensive to measure temperatures in large representative sample of English homes. The temperature sensors were 
placed in the home either by the interviewer and the householder together, or by the householder on their own. One sensor was placed in the main living room and one in the main bedroom. An instruction leaflet was provided for interviewers and householders specifying correct placement of the sensors. While the instructions needed sufficient detail to ensure good placement, it was also important that the instructions were not so detailed as to discourage participants from accommodating the sensors, or encourage participants to ignore the instructions altogether. This trade-off between detail and simplicity of instructions may have reduced the reliability of some temperature measures. Participants were instructed to place the sensors on a shelf or other surface between knee height and head height, to place the sensors away from any heat sources (such as a radiator), to avoid a location which might be in direct sunlight during any part of the day, and to avoid a location near windows or doors. The temperature sensors were self-contained data loggers and the data was only accessed at the end of the study once the sensors had been collected from the homes.

The internal temperature monitoring was carried out over a six month period from 22 July 2007 - 3 February 2008. This time period was chosen as it contained both summer and winter months. Living room and bedroom temperatures were recorded for each 45 minute interval during the monitoring period. This recording interval allowed a long monitoring period whilst still capturing the short term temperature variations. The average temperature over each 45 minute interval was recorded by the temperature sensor at a resolution of $0.1^{\circ} \mathrm{C}$. The Hobo temperature sensors had a reported accuracy of $\pm 0.47^{\circ} \mathrm{C}$ at $25^{\circ} \mathrm{C}$ and calibration measurements were taken before they were installed in the survey homes.

The internal temperature measurements for a single example dwelling over a single day in winter clearly show the pattern of use of the central heating system (Figure 2). The external 
air temperatures in the figure were taken from a nearby Meteorological Office weather station. Between 00:00 - 06:45, the heating system appeared to be not in use and the internal temperature fell as the house lost heat to the cold external air. From 06:45 the heating system switched on and raised the living room internal temperature from $16.5^{\circ} \mathrm{C}$ to a maximum of $19.7^{\circ} \mathrm{C}$ at $09: 45$. Then the heating system appeared to switch off and the living room temperature dropped steadily between 09:45 and 15:45. A second heating period then occurred between 15:45 and 19:30 which raised the living room temperature from $17.1^{\circ} \mathrm{C}$ to $20.6^{\circ} \mathrm{C}$. After 19:30 the heating system appeared to be switched off and the living room temperature fell for the remainder of the evening. This heating pattern, with its early morning and late afternoon heating, is somewhat similar to the weekday default heating regime of 07:00-09:00 hours and 16:00-23:00 hours assumed by the BREDEM model (Anderson et. al. 2002). Both the living room and bedroom temperatures in this dwelling follow a similar pattern, which suggests that they are supplied by the same central heating system. In this dwelling the bedroom is at a lower temperature than the living room but in other dwellings in the study the bedrooms were warmer than the living rooms.

Figure 2 Living room, bedroom and external air temperatures, recorded at 45 minute intervals, for a single house on Monday 10th December 2007

Two variables for each dwelling are calculated using the temperature measurements: the estimated average thermostat setting; and the estimated average daily hours of active central heating use. Active central heating use is defined as times when the heating system is actually supplying heat to the dwelling. Since temperature sensor data for the whole heating season was not available, the calculations were based on the living room internal temperature 
measurements made over the three month period from $1^{\text {st }}$ November 2007 to $31^{\text {st }}$ January 2008. The assumption was made that, for any dwelling during the winter months, if the central heating system was not active (not supplying heat to the dwelling) then the living room internal temperature would fall. This was based on the fact that during winter the external air temperature is often considerably lower than the internal temperatures (as demonstrated in Figure 2) so the heat losses through the building fabric would be high. This assumption may not always hold true and there may be occasional times of high solar gains, high internal gains (from appliances and occupants) or secondary heating use (such as the use of a gas fire or other room heater) when the living room temperature did increase without the use of the central heating. However in this analysis it is assumed that, for the majority of cases, living room temperatures only increased when the central heating system was in use. Based on this assumption, the times when the central heating system was in active use was identified according to the following condition being satisfied:

$$
\mathrm{T}_{\mathrm{LR}, i+1}-\mathrm{T}_{\mathrm{LR}, i}>0
$$

where $T_{L R, i}$ is the living room temperature at time interval $\mathrm{i}\left({ }^{\circ} \mathrm{C}\right)$ and $\mathrm{T}_{\mathrm{LR}, \mathrm{i}}$ is the living room temperature at time interval $\mathrm{i}+1\left({ }^{\circ} \mathrm{C}\right)$

Once the active heating had been identified using Equation 1, the daily amount of time spent with active use of central heating was calculated for each dwelling. For example, the dwelling in Figure 2 had nine occasions of an increase in the living room temperature during the day and therefore would be estimated to have 6.75 hours $(9 \times 0.75$ hours $)$ of active central heating use. In the majority of cases the central heating system was in active use for a large proportion of the day. However visual inspection of the temperature measurements showed that, in some cases where the occupants were clearly not present in the home and the central heating had not been used for several days, there were occasional rises in the living room temperatures. These increases were likely caused not by central heating but by the other potential sources of 
heat gains in dwellings. A rules-based approach was employed to exclude such days and any day which was calculated to have an total active use of central heating of less than 2 hours was judged to be a non-heating day when the heating was not in use. In a similar manner any day with a calculated total active use of central heating of greater than 2 hours was classified as a heating day. Only the identified heating days were used to generate results and the nonheating days were excluded in any further analysis. The estimated average daily hours of active central heating use was then calculated, for weekdays, weekends and all days, using the following equation:

$$
\bar{L}_{h p}=\sum_{i=0}^{n} L_{h p, i}
$$

where $\bar{L}_{h p}$ is the estimated average daily hours of active central heating use (hours); $\mathrm{n}$ is the total number of heating days (based on either weekdays, weekends or all days); and $L_{h p, i}$ is estimated hours of active central heating use of the $i^{\text {th }}$ heating day (hours).

Thermostat settings were calculated from the living room temperature measurements by using daily maximum values. For each heating day, the maximum living room temperature was taken to be the thermostat setting used on that day. Non-heating days, during which the heating system was not in use, were excluded from the thermostat calculations. This approach may overestimate the average thermostat setting if the setting was manually adjusted during the day by the householder and if the room temperature increased above the thermostat setting because of other heat sources (such as internal gains, solar gains or a secondary heating system). However in this analysis it was assumed that the occurrence of these effects was minimal. For each house, the average thermostat setting was calculated using the following equation:

$$
\bar{T}_{t h}=\sum_{i=0}^{n} \hat{T}_{L R, i}
$$


where $\bar{T}_{t h}$ is the average thermostat setting $\left({ }^{\circ} \mathrm{C}\right) ; n$ is the total number of heating days; and $\hat{T}_{L R, i}$ is the maximum living room temperature of the $\mathrm{i}^{\text {th }}$ heating day $\left({ }^{\circ} \mathrm{C}\right)$.

Since this study was a large sample, it was impossible to produce a fine-grained description, for every home, of the many complex factors that interact and impact upon the use of central heating and temperature in homes. That is the value of small- $N$ studies. However, this large representative survey of temperatures in English homes enables generalisation to the population of English homes.

\section{Respondent reported thermostat settings and hours active}

Of the 358 CARB07 participants with gas or oil fired central heating with radiators, 172 provided thermostat settings. The remainder do not report having a room thermostat. A few apparent coding errors have been excluded from analysis. Although nearly all thermostats are marked from $10^{\circ} \mathrm{C}$ to $30^{\circ} \mathrm{C}$, four participants report thermostat settings of $0^{\circ} \mathrm{C}$ and one reports a thermostat setting of $9^{\circ} \mathrm{C}$. These are most likely coding errors and they are excluded from any analysis of respondent reported thermostat settings. ${ }^{\text {iii }}$ Excluding cases less than $10^{\circ} \mathrm{C}$, the mean thermostat setting is $19.2^{\circ} \mathrm{C}$ and three standard deviations above the mean is $29.2^{\circ} \mathrm{C}$. There are three potential outliers. These report thermostat settings of $30^{\circ} \mathrm{C}$, where the next highest reported thermostat setting is $26^{\circ} \mathrm{C}$, so they are clearly disconnected from the remainder of the distribution. To avoid outliers having an undue influence on the statistical tests, any analysis of respondent reported thermostat settings that follows includes only those cases reporting thermostat settings of at least $10^{\circ} \mathrm{C}$ and less than $30^{\circ} \mathrm{C}$. 
Participants with central heating were asked when they have their central heating on (in winter) during a typical weekday and a typical weekend. They stipulated the hours at which the central heating came on and went off - with a maximum of three sets of 'on-off' for each day. Their responses were manually checked for errors (e.g. blank heating times) and inconsistencies with answers to other questions, and corrected wherever reasonably possible. The on-off times were then computed into total weekday and total weekend central heating hours. These were then computed into a weighted average central heating hours per day. Of the 358 CARB07 participants with gas or oil fired central heating with radiators, 343 provided sufficient information to calculate a per day weighted average for the week. There are no potential outliers on these variables.

\section{Respondent reported building demographics}

Interviewers coded participants' accommodation type, but all other building and technology demographic variables are based on responses by participants, since a physical survey of the 427 homes would have been prohibitively expensive.

The main survey of housing in England, the English House Condition Survey, reports dwelling types in the following classifications: small terraced house, medium/large terraced house, semi-detached house, detached house, bungalow, converted flat, low-rise purpose built flat and high-rise purpose-built flat. ${ }^{\text {iv }}$ It was not possible to classify homes in this survey into small and medium size terraces as we did not have the relevant information. Moreover, for the analysis it was important to distinguish between bungalows on the basis of how attached they were to other houses. We did not expect bungalows per se to have different thermostat settings or heating times to other houses. The research team did expect to find a difference between mid-terrace, semi-detached and detached houses. Consequently the dwellings were 
classified into the categories used in the 2001 English House Condition Survey data-set: end terrace, mid terrace, semi-detached, detached, purpose-built flat and converted flat. An end terrace house is either first or last in a row of at least three attached houses.

Participants were not asked in which year-band their home was built, because we needed to classify their homes into two very different year-bands - those used by both the English House Condition Survey and the SAP and BREDEM family of models. Instead participants were asked 'In what year was your home built?' and asked to give their best estimate if they were not certain. The English House Condition Survey reports dwelling age in the following age-bands: pre 1919, $1919-1944,1945-1964,1965$ - 1980, post 1980. There was a need to distinguish between older and newer homes built post 1980, as the authors expected to find a difference in thermostat settings and hours of central heating between these groups. The English House Condition Survey 2006 data available online distinguishes between '1981 to 1990' and 'post 1990' (Communities and Local Government 2008). The 2005 report observes that the energy efficiency rating of the 'post 1990' group is substantially higher than that for the '1981 to 1990' group (Communities and Local Government 2007). This age-band grouping is used in our analysis.

The roof insulation variable was developed using a range of sources. The Reduced Data SAP (Standard Assessment Procedure) is the government-approved system for measuring the energy efficiency of existing dwellings. It includes standardised methods for inferring any missing data (Elmhurst Energy Systems et al. 2006). When roof insulation levels are unknown, the RDSAP infers a level based on the year the building was built. These levels correspond to the building regulations in operation in the year of construction. The authors first classified participants' homes into SAP year-bands. Then a variable was developed 
which assigned the RDSAP2005 assumed roof insulation value to each participant's home. During the interview, participants with lofts were given an explanation of insulation, asked if their lofts were insulated, and then asked the thickness of the insulation, with response options corresponding to the SAP roof insulation levels. 31 participants did not know their roof insulation thickness and 44 reported less insulation than that assumed by RDSAP for a building built in that year. Since RDSAP roof insulation levels for a given SAP year-band reflect the building regulations in operation during that period, the authors decided that it was most likely that participants' roofs had at least the levels of insulation stipulated in the RDSAP. A new roof insulation variable was then developed which assigns the 'best of' the RDSAP assumed and the respondent reported roof insulation thickness. In doing so, it was first assumed that, where a respondent reports more insulation than the RDSAP would assume, the respondent knows their level of loft insulation better than the RDSAP estimates it. Secondly it was assumed that, where a respondent reports less insulation than the RDSAP would assume, that the respondent lives in a more recent dwelling (with higher levels of insulation), and has poor knowledge of their level of loft insulation.

Participants were given an explanation of draught-proofing and asked what proportion of their windows were draught-proofed. Response options were: all, most, about half, some, and none. Several respondents reported a lower proportion of windows draught-proofed than doubleglazed. It is unlikely that windows would be double-glazed and not draught-proofed. Consequently, where respondents reported a higher level of double-glazing than draughtproofing, the draught-proofing variable assigned the response given to the double-glazing question. 
Participants with central heating were asked which of the following controls they have on their central heating: 1) room thermostat or roomstat, 2) a time clock, timer or programmer, 3) thermostatic radiator valve (TRV), 4) controller or programmable room thermostat. ${ }^{\mathrm{v}}$ Those participants reporting a room thermostat, roomstat, controller or programmable room thermostat were assigned the value 'roomstat' on the variable 'temperature control'. Those reporting none of these, but reporting a TRV were assigned the value 'TRV only' on the variable 'temperature control'. Participants reporting the presence of time control (a time clock, timer, programmer, controller or programmable room thermostat) were also asked if they normally run the central heating with the timer, or manually. Those without time control of their central heating system (13\%) and those with time control, but who normally run their system manually (22\%) were assigned the value 'manual operation' on the variable 'timer or manual operation'.

\section{Results}

\section{Overview}

Overview statistics for dwelling type and age, and respondent reported presence of central heating system controls are provided in Table 1.

\section{Table 1 Building demographics}

Overview statistics for the dependent variables - estimated and reported thermostat settings and estimated active and reported central heating hours per day - are outlined in Table 2, together with the central heating hours for weekdays and weekends. 
Table 2 Central heating thermostat settings and durations

There is enormous variation in both estimated and reported thermostat settings, as indicated in the standard deviations in Table 2 and in the wide distributions in Figure 3 and Table 3. Although both the mean and the median estimated thermostat setting are $21^{\circ} \mathrm{C}$, the standard deviation is $2.5^{\circ} \mathrm{C}$ (Table 2). Furthermore, while $30 \%$ of the sample has estimated thermostat settings of less than $20^{\circ} \mathrm{C} ; 40 \%$ has estimated thermostat settings of $22^{\circ} \mathrm{C}$ or higher (Table 3 ).

Figure 3 Thermostat settings - estimated and reported

Table 3 Thermostat settings estimated and reported

There is much less variability in the estimated number of hours per day that the central heating is active (mean and median 8.4, S.D 1.5 - see Table 2 and Figure 4). In contrast there is a great deal of variability in the reported number of hours that the central heating is on (mean 9.5, median 8.0, S.D. 5.4 - see Table 2 and Figure 4).

Figure 4 Central heating hours - reported on-duty and estimated active

\section{Thermostat settings}

Thermostat settings estimated from the temperature sensors and reported by respondents are explored by building demographics in Table 4 . 
Table 4 Central heating thermostat settings estimated and reported - by building demographics

For estimated thermostat settings, there was a statistically significant difference amongst levels of window double-glazing and draught-proofing $(F=6.13, p=0.003$ and $F=5.37, p=$ 0.005 respectively for the one-way ANOVAs for unrelated samples). The Scheffé post-hoc multiple comparisons indicated that the most statistically significant mean difference in estimated thermostat settings $\left(1.7^{\circ} \mathrm{C}\right.$ in both cases) was that between all and some (doubleglazed $\mathrm{p}=0.007,95 \%$ C.I. $=0.4,2.9$; draught-proofed $\mathrm{p}=0.007,95 \%$ C.I. $=0.4,3.1)$. In other words, homes with all windows double-glazed or draught-proofed had significantly higher estimated thermostat settings than homes with some windows double-glazed or draught-proofed. No statistically significant difference exists between estimated thermostat settings in different geographical regions.

In the sample, homes without thermostatic control of the central heating system had mean estimated thermostat settings $0.6^{\circ} \mathrm{C}$ below those with thermostatic control (room thermostat or thermostatic radiator valve). However, the one-way ANOVAs for unrelated samples indicated that this difference was not statistically significant $(F=1.14, p=0.32)$.

No correlation was found between estimated and reported central heating thermostat settings - as indicated in Figure 5. There was a slight increase in the correlation when only those homes with room thermostats in the main living room were selected - which was also the location of the temperature sensors $(r=0.23)$, but the correlation was not statistically significant $(p=0.33)$, although the lack of statistical significance may be somewhat due to the 
small sample size $(n=20)$. There was no increase in correlation when we selected only those cases using solely central heating in the main living room, or when we selected more energy efficient homes (purpose-built flats, or those built after 1990, or those with the most roof insulation, or those with all windows double-glazed).

Figure 5 Thermostat settings - reported vs. estimated

\section{Hours of use per day}

Central heating active hours per day, as estimated from the temperature sensors, and central heating hours on per day, as reported by respondents, are both explored by building demographics in Table 5.

Table 5 Central heating estimated active hours per day and reported hours on per day - by building demographics

For both central heating estimated active hours and respondent reported central heating on hours, there was a statistically significant difference between accommodation types $(F=3.69$ ,$p=0.007 ; F=2.58, p=0.04$ respectively for the one-way ANOVAs for unrelated samples). The Scheffé post-hoc multiple comparisons indicated that the most statistically significant mean difference in both estimated active hours and reported hours is between detached and mid-terrace houses - with detached houses heated for longer. For estimated active hours the mean difference is 1.1 hours $(p=0.03,95 \%$ C.I. $=0.1,2.0)$. For reported hours the mean difference is 2.6 hours $(p=0.09 ; 95 \%$ C.I. $=0.2,5.4)$. 
For estimated active central heating hours, there was a difference amongst levels of window draught-proofing, but this difference was not statistically significant at the $p=0.05$ level $(F=$ 2.3, $p=0.1$ for the one-way ANOVAs for unrelated samples). Scheffé post-hoc multiple comparisons indicated that the most statistically significant mean difference in estimated active hours per day (1.1 hours) is between those with all and no windows draught-proofed $(p=0.11 ; 95 \%$ C.I. $=-0.2,2.4)$. Note that only 9 cases have no draught-proofing and that if there were more cases in this group, the statistical significance of this test may have improved.

Households using timers have mean estimated active central heating hours 0.4 hours longer than those using manual operation. However, the $t$-test for the equality of two means indicates this difference is not statistically significant at the $p=0.05$ level $(t=1.73 ; p=0.09 ; 95 \%$ C.I. $=-0.1,0.9)$.

Although Government Office Region had a statistically significant effect on reported central heating hours according to the one-way ANOVA for unrelated samples $(F=1.9, p=0.06)$, the Scheffé post-hoc multiple comparisons indicated that the most statistically significant mean difference in reported hours per day (between the South East and London) was not statistically significant $(p=0.60 ; 95 \%$ C.I. $=-1.6,7.2)$. No statistically significant difference was found between estimated active central heating hours in different geographical regions. 


\section{Discussion}

\section{Difficulties measuring building demographics}

This study relied on respondents knowing and accurately reporting on their homes' building fabric and heating technology. A future study could usefully compare respondents' reports with those of building surveyors.

Several of the measured building demographic variables required careful development to allow harmonization with two or more measurement methods. For instance, the authors needed to classify homes into two very different year-bands - that used by the English House Condition Survey and that used by the BREDEM family of models. Consequently, instead of asking our participants in which year-band their home was built, they were asked in which year their home was built. In other cases, the authors had to choose one measurement method and forego the policy usefulness of being able to report our home energy survey findings with reference to both the EHCS and BREDEM.

The EHCS and its successor the English Housing Survey, is the main source of government information on housing and the energy efficiency of housing in England. The BREDEM is a family of models that are used by government in two main ways. Firstly, in the form of SAP for the energy rating of dwellings, they are used as a regulatory instrument (DEFRA 2008c). Secondly, in the form of BREHOMES, the UK housing stock model, they inform much UK government policy through the Domestic Energy Fact File (DEFF). Most core 'building demographic' variables are measured differently by the EHCS and BREDEM, despite the need for government policy to draw on them both simultaneously. 
Over twenty years ago in the U.S., Vine (1986) called for home energy use surveys to use standardised measurement instruments. The UK Office of National Statistics (2003) leads a cross-government programme of work harmonising key socio-demographic measurement instruments and output variables. This work enables robust comparisons and integration of information across surveys. Serious consideration should be given to developing harmonised building demographic variables. This could enable information from the new English Housing Survey to be integrated with the BREDEM family of models, thus providing a more robust framework for energy policy making.

\section{Variability in thermostat settings and hours active}

Enormous variation was found in both estimated and reported thermostat settings - standard deviations were $2.5^{\circ} \mathrm{C}$ and $3.0^{\circ} \mathrm{C}$ respectively. This echoes the findings of many other studies. Hunt and Gidman (1982) found a standard deviation of $3.0^{\circ} \mathrm{C}$ in living room temperatures in their survey of 1000 homes (mean $18.3^{\circ} \mathrm{C}$ ). [Due to differences in temperature measurement method, their mean living room temperature is not comparable to our mean estimated thermostat setting.] Rathouse and Young (2004) found wide variation in reported winter warmth preferences in their focus groups. Vine (1986) found great variability in reported summer and winter thermostat settings and Hackett and McBride (2001) found variation with respect to household cooling temperature preferences. Woods (2006) found wide variations in thermostat set points in their study of heating and cooling thermostat settings in California. Humphreys (1995) and the reviews by Shove et. al (2008), Nicol and Roaf (2005) and Brager and de Dear (1998) note the huge variation in temperatures that individuals can find thermally comfortable, even within the same society. For Chappells and Shove (2005) this variability is a policy opportunity, as it suggests a wide range of possibilities for providing thermal 
comfort, beyond just internal building temperatures. A policy option they suggest is encouraging the development of new insulative clothing technologies.

Although both the mean and median estimated thermostat setting were $21^{\circ} \mathrm{C}, 30 \%$ of our sample had settings of less than $20^{\circ} \mathrm{C}$ and $40 \%$ had settings of $22^{\circ} \mathrm{C}$ or higher. In his testimony to the U.S. House of Representatives hearing on the contribution of the social sciences to the energy challenge, and in his academic publications, Cialdini (2007a, 2007b, 2007c) points out that people are heavily influenced by what other people actually do. If good behaviour is the norm and this is publicised, people are motivated toward the good behaviour in order to be 'part of the crowd'. Social marketing programs could use the wide variation in thermostat settings to encourage those with high thermostat settings (say $22^{\circ} \mathrm{C}$ or higher) to set them at a more 'normal' level $\left(21^{\circ} \mathrm{C}\right)$. In such a program it would also be very important to applaud existing good behaviour, or those already behaving better than average will also tend to behave more 'normally' (Schultz, Nolan, et. al. 2007). Social psychology and social marketing authors have a wealth of other advice relevant to any such program - see, for instance, Cialdini (2003, 2007a, 2007b, 2007c), Goldstein \& Cialdini (2007), Mckenzie-Mohr (1994, 2000), McKenzie-Mohr \& Smith (1999), National Research Council Committee on the Human Dimensions of Global Change (2002), Shipworth (2000), Steg (2008) and Stern (1992).

A great deal of variation was found in the reported number of hours per day that the central heating is on - the standard deviation was 5.4 hours. Likewise the 1996 English House Condition Survey found a large variation (standard deviation of 6.4 hours per day) in the duration for which regularly heated living rooms were reportedly heated (DETR 2000). In contrast, the current study found relatively little variation in the estimated number of hours 
per day that the central heating is active - the standard deviation was just 1.5 hours per day. However, the range varied from 4.7 to 12.7 hours per day. In comparison, Martin and Watson (2006), found daily heating periods varied from 2 to 20 hours. Theirs was a study of 59 homes in central England which had received insulation upgrades. They calculated heating patterns from temperature loggers placed on the heating system itself, their data was collected between October 2004 and May 2005, although the period of data collection varied. On the other hand, our estimated central heating hours per day were averaged over a three-month period.

\section{Building energy efficiency - its influence on thermostat settings and hours active}

Detached houses are heated for significantly longer than mid-terrace houses, according to this study's findings. There is a statistically significant difference in the mean number of hours both for the estimated active hours (mean difference $=1.1$ hours, $p=0.03,95 \%$ C.I. $=0.1,2.0$ ) and for respondent reported hours (mean difference $=2.6$ hours, $p=0.09 ; 95 \%$ C.I. $=0.2$, 5.4). On the other hand, Hunt and Gidman (1982) found no statistically significant differences between the internal temperatures of different dwelling types (other than converted flats, which are not considered in our study). The current findings suggest that detached houses, with more exposed walls, are being heated for longer, in order to provide the same internal temperatures as found in mid-terrace houses, and should be particularly targeted for energy efficiency improvements.

The energy efficiency rating scheme for homes - the Standard Assessment Procedure, or SAP - assumes that living room temperatures in the most energy efficient homes are on average $1.1^{\circ} \mathrm{C}$ higher than those in the least energy efficient dwellings (BRE 2008). The 1996 English House Condition Survey provides evidence for this (DETR 2000), as does the study of low- 
income recipients of the Warm Front home energy efficiency improvements grant scheme (Oreszczyn et al. 2006).

Statistically significant higher estimated thermostat settings (average daily maximum living room temperatures) were found in homes with all windows double-glazed or draught-proofed, when compared to homes with some double-glazing or draught-proofing. For both doubleglazing and draught-proofing, the mean difference was $1.7^{\circ} \mathrm{C}$ (double-glazed $\mathrm{p}=0.007,95 \%$ C.I. $=0.4,2.9$; draught-proofed $p=0.007,95 \%$ C.I. $=0.4,3.1)$. This could simply be further evidence that energy efficient homes are able to be maintained at a warmer temperature than less efficient homes. However, it could also be evidence of some 'takeback' - people in more energy efficient homes demanding a higher level of energy service than people in less efficient homes.

Homes with all windows draught-proofed have the central heating active for 1.1 hours longer per day than homes with no windows draught-proofed - although this difference is not statistically significant $(p=0.11 ; 95 \%$ C.I. $=-0.2,2.4)$. Only 9 of our cases have no draughtproofing; if there were more cases it is possible that the mean difference would be more statistically significant. If it were simply the case that energy efficient homes were warmer because they were more insulated, we would expect the central heating in 'all windows draught-proofed' homes to be active for fewer hours than the 'no windows draught-proofed' group. However, this is not the case, suggesting that higher standards of comfort may be being demanded in more energy efficient homes. 


\section{Central heating controls - their influence on thermostat settings and hours active}

As indicated in Table 1, the survey respondents report a much lower presence of central heating system controls in 2007 than surveyors found in the 2001 English House Condition Survey (BRE 2005b). The difference is particularly noticeable for room thermostats $-56 \%$ versus $72 \%$ for the subsamples with gas or oil fired central heating systems with radiators $\left(X^{2}\right.$ $=50, d f=1, p<0.0001)$, although there is also a significant and large difference in reported presence of timers $-87 \%$ versus $98 \%\left(X^{2}=186, d f=1, p<0.0001\right)$.

The current findings suggest that many respondents do not realise they have room thermostats. Certainly Karjalainen (2007) found that Finnish office workers seemed to not recognise a room thermostat and Rathouse and Young (2004) found that many English householders participating in their focus groups did not understand the difference between room and boiler thermostats. The Energy Information Administration of the US Department of Energy found that the proportion of households reporting the presence of a programmable thermostat seemed to vary markedly depending on where in the interview the question was asked (EIA 1999). In 1997 nearly three times as many households reported having a programmable thermostat than did in 1993. However, in 1993 the question was placed in the section on conservation measures and in 1997 the question was placed in the space-heating section. In our study, the questions on central heating system controls were placed directly after a set of questions about the types of heating present in the home.

UK Government regulations, policies and programs assume that adding controls to a central heating system will reduce the energy use of that heating system. The building regulations through SAP 2005 - assume that adding thermostatic control to a boiler-radiator central 
heating system will reduce living room temperatures by $0.6^{\circ} \mathrm{C}$ (BRE 2008). The Energy Saving Trust (2008) claims that adding heating controls will reduce heating bills by about 17\%. DEFRA (2008c) expects that educating householders to use their central heating controls 'correctly' will help significantly towards plans to reduce energy use from domestic heating and hot water systems by $3.5 \%$ by 2020 .

In contrast to these expectations, the sample homes without thermostatic control of the central heating system had mean estimated thermostat settings (average maximum temperatures) $0.6^{\circ} \mathrm{C}$ below those with thermostatic control However, this difference was not statistically significant, so this finding is that there no statistically significant differences exist in average maximum living room temperatures between homes with and without thermostatic control on their central heating systems. Furthermore, it was found that central heating systems operated by timer are active 0.4 hours per day longer than those operated manually, although the difference is not quite statistically significant $(p=0.09 ; 95 \%$ C.I. $=-0.1,0.9)$. These findings should not come as a surprise. A 1986 study of room air-conditioner use in Californian apartments found that the estimated 'cooling' electricity consumption of air conditioners driven manually was $21 \%$ less than that of those driven automatically (Lutzenhiser 1992).

Conner \& Lucas (1990) also found that clock thermostats did not significantly increase the incidence of thermostats being setback, in their study of over 400 single-family, electrically heated homes in the northwest US. However, they did find that homes with clock thermostats were $0.4^{\circ} \mathrm{C}$ cooler than those with manual thermostats. In their study of nearly 300 Wisconsin households, Nevius \& Pigg (2000) found homes with programmable thermostats used about the same amount of energy for space-heating as those with manual thermostats did. One of the reasons was that many of the households using manual thermostats set back their 
temperatures manually. Parker, in Sachs (2004) found that homes with programmable cooling thermostats had a lower seasonal average temperature than homes with manual thermostats, and used more cooling energy. This suggests that occupants with programmable thermostats might be setting the cooling to turn on before they arrive home, whereas occupants with manual thermostats can only turn the cooling on once they are home.

In stark contrast with all of these studies, RLW Analytics (2007) found that installation of an ENERGY STAR rated programmable thermostat in U.S. homes resulted in a $6.2 \%$ reduction in total household annual natural gas consumption $(90 \%$ C.I. $=4.7,7.7)$. Their experimental study compared survey and billing data from 683 'test' households with that on 1,264 'control' households. They argue that the reason for the contrast between their findings and those of earlier studies, is that their study is of newer programmable thermostats, which are more user-friendly, easier to use and thus more likely to change householder's behaviour.

In conclusion, central heating system controls seem to live incognito in many homes. Furthermore, when controls are used, there may be no reduction in average maximum temperatures and possibly even an increase in operational durations - although the findings are somewhat contradictory. These findings suggest that central heating system controls may require radical re-evaluation if their future use is to result in energy savings. Karjalainen (2007) used a user-centred approach to develop new office thermostat user interfaces that were more understandable and acceptable to users. Shove, Watson et. al. (2007) recommend moving beyond a user-centred approach to a "practice oriented product design" approach that also pays attention to the relations between interconnected practices - i.e. to systems of practices. 


\section{Estimated and reported thermostat settings}

No correlation was found between estimated and reported central heating thermostat settings, even when selecting the more energy efficient dwellings. This contrasts with Vine and Barnes (1989), who found households in highly energy efficient houses had small differences between measured temperatures and reported thermostat settings. The literature provides three main explanations for the lack of correlation between the two.

Firstly, in a study of home energy use, social desirability response bias may prompt householders to report lower thermostat settings than they actually maintain (de Vaus 2002b). If this were the primary explanation, however, one would still expect to see a correlation between reported and estimated thermostat settings. In this situation the regression equation for estimated thermostat settings would be expected to contain a positive constant coefficient and/or a slope coefficient greater than one - to convert low reported thermostat settings into higher estimated thermostat settings.

Secondly, householders seem to not understand thermostats in the way that engineers do. In Hackett and McBride's (2001) interviews with Californian householders, they found that people hesitate to describe thermal comfort in numerical terms. As already mentioned, Karjalainen's (2007) qualitative study found that Finnish office workers seemed to not recognise a room thermostat when it was shown to them, or understand its purpose. In particular, workers did not understand the symbols on the thermostat and were dissatisfied with the feedback they received from the heating system. In the current survey, around $25 \%$ less respondents reported having room thermostats than would be expected from government housing surveys. This suggests that many of our respondents may not realise they have room thermostats. Indeed, as mentioned above, Rathouse and Young (2004) found that many 
English householders did not understand the difference between room and boiler thermostats and did not know how to use these controls.

Finally, householders may adjust their thermostats fairly frequently. Certainly, Woods (2006) found in their Californian study that people changed both heating and cooling thermostat set points very frequently. We asked participants for a single thermostat setting. However, this may not adequately represent their use of their thermostats and indeed many authors point out that individuals tend to adjust thermostats according to conditions, occupancy and their own varying preferences (Vine 1986, Hackett and McBride 2001, Shove et. al. 2008). This tendency to adjust thermostats is exacerbated due to members of the same household often preferring different temperatures (Rathouse and Young 2004). Moreover Kempton (1984) found that a significant minority of households turn the thermostat up high in the (erroneous) belief that the home will heat up faster, and then turn it down when the home is warm enough. The estimated thermostat settings are, in effect, the estimated average daily maximum temperature, whereas reported thermostat settings may be the household's typical daily thermostat settings.

\section{Conclusion}

UK Government regulations (e.g. SAP), policies (e.g. from DEFRA) and programs (e.g. of the Energy Saving Trust) assume that adding controls to central heating systems will reduce their energy use. However, findings from this study suggest that households that use central heating system controls have no lower demand temperatures or durations than households that do not use controls. However, the experiment conducted by RLW Analytics (2007) suggests that adding modern central heating system controls does reduce energy consumption. 
The efficiency of data collection can and should be substantially improved. UK government home energy conservation policies rely on the BREDEM family of models for regulation (the SAP) and policy direction (BREHOMES). However, the most important source of data on English homes is the English Housing Survey and data from this survey is of limited use for informing SAP regulations and BREHOMES-informed policies - for two reasons. Firstly, many key building demographic variables are measured differently in the English Housing Survey and the BREDEM family of models. Secondly, the English Housing Survey does not collect data on energy consumption. This results in both a duplication of data-gathering effort and a dearth of data from representative samples of the population. Evidence-informed energy policies require far more coordinated data collection and management.

Policies and programs could fruitfully target specific groups of homes and households. Firstly, detached houses are heated for significantly longer, so energy efficiency retrofit programs should target them early on. Secondly, social marketing programs could use this study's evidence on average thermostat settings as a basis for a 'social norm' social marketing program aimed at reducing temperatures in 'overheated' homes.

Many people may not recognise or understand their central heating system controls. Programs could be developed to help them understand and operate their existing heating controls more efficiently. Furthermore, new controls should be developed that appeal to householders, are intuitively useable by them and make it easy for householders to reduce their heating energy use. $^{\text {vi }}$. 


\section{Acknowledgements}

This work forms part of Carbon Reduction in Buildings (CaRB) Consortium. CaRB had 5 UK partners: De Montfort University, University College London, the University of Reading, the University of Manchester and the University of Sheffield. CaRB was supported by the Carbon Vision initiative which is jointly funded by the Carbon Trust and Engineering and Physical Sciences Research Council, with additional support from the Economic and Social Research Council and Natural Environment Research Council. The partners were assisted by a steering panel of representatives from UK industry and government. See http://www.carb.org.uk for further details. Anonymous reviewers for this journal provided extremely useful feedback on an earlier draft of this paper, and references to some recent U.S. studies.

\section{References}

Anderson, B. R., Chapman, P. F., Cutland, N. G., Dickson, C. M., Doran, S. M., Henderson, G., Henderson, J. H., Iles, P. J., Kosmina, L. and Shorrock, L. D. (2002) BREDEM-8 Model description: 2001 update, Garston, Watford, UK, Building Research Establishment, Department for Environment, Food \& Rural Affairs.

Boardman, B. (2007) Examining the carbon agenda via the 40\% House scenario. Building Research \& Information, 35, 363-378.

Brager, G. S. and de Dear, R. J. (1998) Thermal adaptation in the built environment: a literature review. Energy and Buildings, 27, 83-96.

BRE (2005a) SAP2005. Garston, Watford, Building Research Establishment. 
BRE (2005b) Space and Water Heating. Energy Use in Homes: A series of reports on domestic energy use in England. London, Department for Environment, Food and Rural Affairs \& Energy Saving Trust.

BRE (2008) The Government's Standard Assessment Procedure for Energy Rating of Dwellings 2005 edition, revision 1. Garston, Watford, BRE.

CCC (2008) Building a low-carbon economy - The UK's contribution to tackling climate change (The First Report of the Committee on Climate Change) Executive Summary. London, Committee on Climate Change.

Chappells, H. and Shove, E. (2005) Debating the future of comfort: environmental sustainability, energy consumption and the indoor environment. Building Research \& Information, 33, 32-40.

Cialdini, R. B. (2003) Crafting normative messages to protect the environment. Current Directions in Psychological Science, 12, 105-109.

Cialdini, R. B. (2007a) Testimony to the hearing on: The Contribution of the Social Sciences to the Energy Challenge. U.S. House of Representatives Committee on Science and Technology, Subcommittee on Research and Science Education. Washington D.C.

Cialdini, R. B. (2007b) Using Social Norms To Preserve The Environment. Behavior, Energy \& Climate Change Conference. Sacramento, CA Precourt Institute for Energy Efficiency at Stanford University.

Cialdini, R. B. (2007c) Descriptive Social Norms as Underappreciated Sources of Social Control. Psychometrika, 72, 263-268. 
Communities and Local Government (2007) English House Condition Survey - 2005 Annual Report. London, Department for Communities and Local Government.

Communities and Local Government (2008) EHCS Standard Tables - Summary Statistics 2006. Available from

http://www.communities.gov.uk/housing/housingresearch/housingsurveys/englishhousecondit ion/ehcsdatasupporting/ehcsstandardtables/ [Accessed 17 July 2009].

Conner, C. C. and Lucas, R. L. (1990) Thermostat Related Behavior and Internal Temperatures Based on Measured Data in Residences. PNL-7465. Richland, WA, Pacific Northwest Laboratory.

de Vaus, D. (2002a) Analyzing Social Science Data, London, Sage.

de Vaus, D. (2002b) Surveys in Social Research (5th ed.), London, Routledge.

DECC (2009) Heat and Energy Saving Strategy: Consultation. Department of Energy \& Climate Change.

DEFRA (2006) Climate Change: The UK Programme 2006. London, Department for Environment Food and Rural Affairs.

DEFRA (2008a) UK Climate Change Programme: Annual Report to Parliament. London, Department for Environment Food and Rural Affairs.

DEFRA (2008b) Climate Change Act 2008. Department for Environment Food and Rural Affairs. Available from http://www.defra.gov.uk/environment/climatechange/uk/legislation/index.htm. 
DEFRA (2008c) Policy Brief: Improving the energy performance of domestic heating and hot water systems. London, Department for Environment Food and Rural Affairs.

DETR (2000) English House Condition Survey 1996: Energy report. London, Department of the Environment Transport and the Regions.

EIA (1999) A Look at Residential Energy Consumption in 1997. Washington DC, Energy Information Administration, U.S. Department of Energy.

Elmhurst Energy Systems, MVM Consultants and National Energy Services (2006) Reduced data SAP - Collected data set: RDSAP v3 (RDSAP 2005). FAERO (on behalf of DEFRA).

Energy Saving Trust (2008) Heating Controls. http://www.energysavingtrust.org.uk/Homeimprovements/Heating-and-hot-water/Heating-controls.

Enviros Consulting (2008) The Potential for Behavioural and Demand-Side Management Measures to Save Electricity, Gas and Carbon in the Domestic Sector, and Resulting SupplySide Implications - Report for DECC. Department of Energy and Climate Change.

Goldstein, N. J. and Cialdini, R. B. (2007) Yes! 50 secrets from the science of persuasion, London, Profile Books.

Griffiths, I. D. (1987) Human factors in domestic gas consumption in South-East England, 1981-1985 (computer file). UK Data Archive SN 2193. Colchester, Essex, UK Data Archive (distributor).

Hackett, B. and McBride, R. (2001) Human Comfort Field Studies. IN Davis Energy Group (Ed.) Deliverable for Sub-task 2.3.5: Alternatives to Compressor Cooling Project. Davis, California, California Energy Commission Contract No. 500-98-024. 
Hitchcock, G. (1993) An integrated framework for energy use and behaviour in the domestic sector. Energy and Buildings, 20, 151.

Humphreys, M. A. (1995) Thermal comfort temperatures and the habits of Hobbits. IN Nicol, F., Humphreys, M. A., Sykes, O. and Roaf, S. (Eds.) Standards for thermal comfort : indoor air temperature standards for the 21st century. Chapman \& Hall.

Hunt, D. and Gidman, M. (1982) A national field survey of house temperatures. Building and Environment, 17, 107-124.

Johnston, D., Lowe, R. and Bell, M. (2005) An exploration of the technical feasibility of achieving $\mathrm{CO}_{2}$ emission reductions in excess of $60 \%$ within the UK housing stock by the year 2050. Energy Policy, 33, 1643-1659.

Karjalainen, S. (2007) The characteristics of usable room temperature control [Huonelämpötilan hallinnan käyttöliittymät. Käytettävyyden tarkasteluja toimistoympäristössä]. VTT Publications 662. Espoo, Finland, VTT Technical Research Centre of Finland.

Kempton, W. (1984) Two Theories Used for Home Heat Control. IN Morrison, B. M. and Kempton, W. (Eds.) Familes and Energy: Coping with Uncertainty (Conference Proceedings. Institute for Family and Child Study, College of Human Ecology). Lansing, Michigan, Michigan State University Press.

King's Lynn and West Norfolk Borough Council (2008) Energy efficient heating. Available from http://www.west-norfolk.gov.uk/Default.aspx?page=22439, [Accessed 29 January 2009]. 
Lutzenhiser, L. (1992) A Question Of Control - Alternative Patterns Of Room AirConditioner Use. Energy And Buildings, 18, 193-200.

Market Transformation Programme (2005) Sustainable Products 2005: Policy Analysis and Projections. Didcot, www.mtprog.com.

Market Transformation Programme (2006) Evaluation of heating controls - Phase 1.

RPDH19. Didcot, Market Transformation Programme - DEFRA.

Martin, C. and Watson, M. (2006) Measurement of energy savings and comfort levels in houses receiving insulation upgrades. Energy Monitoring Company for the Energy Saving Trust.

McKenzie-Mohr, D. (1994) Social Marketing For Sustainability - The Case Of Residential Energy-Conservation. Futures, 26, 224.

McKenzie-Mohr, D. (2000) Promoting Sustainable Behavior: An Introduction to CommunityBased Social Marketing. Journal of Social Issues, 56, 543-554.

McKenzie-Mohr, D. and Smith, W. (1999) Fostering Sustainable Behavior: An Introduction to Community-Based Social Marketing, Gabriola Island, Canada, New Society Publishers.

Natarajan, S. and Levermore, G. J. (2007) Predicting future UK housing stock and carbon emissions. Energy Policy, 35, 5719-5727.

National Research Council, Committee on the Human Dimensions of Global Change, Dietz, T. and Stern, P. C. (Eds.) (2002) New Tools for Environmental Protection: Education, Information, and Voluntary Measures, Washington, D.C., National Academy Press. 
Nevius, M. J. and Pigg, S. (2000) Programmable Thermostats that Go Berserk? Taking a Social Perspective on Space Heating in Wisconsin. ACEEE Summer Study in Energy Efficiency in Buildings.

Nicol, F. and Roaf, S. (2005) Post-occupancy evaluation and field studies of thermal comfort. Building Research \& Information, 33, 338-346.

Office for National Statistics (2003) Guide to Harmonisation: How we're making comparisons easier. National Statistics. Available from http://www.statistics.gov.uk/CCI/nugget.asp?ID=506 [Accessed 25 January 2009].

Oreszczyn, T., Hong, S. H., Ridley, I., Wilkinson, P. and The Warm Front Study Group (2006) Determinants of winter indoor temperatures in low income households in England. Energy and Buildings, 38, 245-252.

Oreszczyn, T. and Lowe, R. (2004) Memorandum. House of Lords Select Committee on Science and Technology Minutes of Evidence. London, The Stationery Office.

Rathouse, K. and Young, B. (2004) Domestic Heating: Use of Controls. Report ID: RPDH15. Didcot, Market Transformation Programme (DEFRA).

RLW Analytics (2007) Validating the Impact of Programmable Thermostats. Middletown, CT, Prepared for GasNetworks by RLW Analytics.

Sachs, H. M. (2004) Programmable Thermostats. Washington, DC, American Council for an Energy Efficient Economy.

Schultz, P. W., Nolan, J. M., Cialdini, R. B., Goldstein, N. J. and Griskevicius, V. (2007) The Constructive, Destructive, and Reconstructive Power of Social Norms. Psychological Science, $18,429-434$. 
Shipworth, M. (2000) Motivating Home Energy Action: A handbook of what works.

Canberra, Australia, Australian Greenhouse Office. Available from http://nla.gov.au/nla.arc51207.

Shorrock, L. D. and Dunster, J. E. (1997) The physically-based model BREHOMES and its use in deriving scenarios for the energy use and carbon dioxide emissions of the UK housing stock. Energy Policy, 25, 1027-1037.

Shove, E., Chappells, H., Lutzenhiser, L. and Hackett, B. (2008) Editorial: Comfort in a lower carbon society. Building Research \& Information, 36, 307 - 311.

Shove, E., Watson, M., Hand, M. and Ingram, J. (2007) The Design of Everyday Life, Oxford, Berg.

Steg, L. (2008) Promoting household energy conservation. Energy Policy, 36, 4449-4453.

Stern, P. C. (1992) What Psychology Knows About Energy-Conservation. American Psychologist, 47, 1224-1232.

United Kingdom. The Climate Change Act 2008 (2020 Target, Credit Limit and Definitions) 2009. Office of Public Sector Information. Available from http://www.opsi.gov.uk/si/si2009/uksi_20091258_en_1.

Vine, E. L. (1986) Saving energy the easy way: An analysis of thermostat management. Energy, 11, 811-820.

Vine, E. L. and Barnes, B. K. (1989) Monitored Indoor Temperatures And Reported Thermostat Settings - How Different Are They. Energy, 14, 299.

Woods, J. (2006) Fiddling with Thermostats. ACEEE Summer Study on Energy Efficiency in Buildings. 


\section{Table 1 Building demographics}

Table 1 Building demographics

\begin{tabular}{|c|c|c|c|}
\hline & CaRB 2007 & CaRB 2007 & EHCS \\
\hline & $\mathbf{N}$ & $\%$ & $\%$ \\
\hline \multicolumn{4}{|l|}{ Accommodation Type $^{a}$} \\
\hline End Terrace & 35 & 9.8 & 11.3 \\
\hline Mid Terrace & 53 & 14.8 & 21.4 \\
\hline Semi Detached & 110 & 30.7 & 29.7 \\
\hline Detached & 109 & 30.4 & 13.9 \\
\hline Purpose Built Flat & 32 & 8.9 & 20.4 \\
\hline Other & 19 & 5.3 & 3.3 \\
\hline$x^{2}$ & 106.1 & & \\
\hline$d f$ & 5 & & \\
\hline$p$ & $<0.0001$ & & \\
\hline \multicolumn{4}{|l|}{ Accommodation Year ${ }^{b}$} \\
\hline Pre 1919 & 51 & 14.3 & 21.7 \\
\hline 1919 to 1944 & 70 & 19.7 & 18.2 \\
\hline 1945 to 1964 & 83 & 23.3 & 19.8 \\
\hline 1965 to 1980 & 76 & 21.3 & 22.0 \\
\hline 1981 to 1990 & 41 & 11.5 & 8.3 \\
\hline Post 1990 & 35 & 9.8 & 9.9 \\
\hline$x^{2}$ & 16.1 & & \\
\hline$d f$ & 5 & & \\
\hline$p$ & 0.007 & & \\
\hline \multicolumn{4}{|c|}{ Reported Presence of Central Heating System Controls ${ }^{c}$} \\
\hline Room Thermostat & 199 & 55.7 & 72.4 \\
\hline None & 158 & 44.3 & 27.6 \\
\hline$x^{2}$ & 50.0 & & \\
\hline$d f$ & 1 & & \\
\hline$p$ & $<0.0001$ & & \\
\hline
\end{tabular}




\begin{tabular}{lrrr}
\hline & CaRB 2007 & CaRB 2007 & EHCS \\
N & \% & $\%$ \\
\hline Room Thermostat or Thermostatic Radiator Valves & 276 & 77.3 & 87.8 \\
None & 81 & 22.7 & 12.2 \\
$X^{2}$ & 36.7 & & \\
$d f$ & 1 & & \\
$p$ & $<0.0001$ & & \\
& & & \\
Timer & 309 & 86.6 & 97.6 \\
None & 48 & 13.4 & 2.4 \\
$X^{2}$ & 185.9 & & \\
$d f$ & 1 & & \\
$p$ & $<0.0001$ & & \\
\hline
\end{tabular}

${ }^{\mathrm{a}}$ Dwelling types - CaRB data is compared to raw data from the 2001 English House

Condition Survey, as explained in the methods section.

${ }^{\mathrm{b}}$ Dwelling age - CaRB data is compared to the 2006 English House Condition Survey data (Communities and Local Government 2008).

${ }^{\mathrm{c}}$ Reported presence of central heating system controls - CaRB data is compared to English House Condition Survey 2001 - weighted averages for gas or oil fired boiler central heating systems with radiators (derived from Tables 1.9 and 1.14 in BRE 2005b). 


\section{Table 2 Central heating thermostat settings and durations}

Table 2 Central heating thermostat settings and durations

\begin{tabular}{lrrrrr}
\hline Variable & Mean & S.D. & Median & N & 95\% C.I. \\
\hline Thermostat Setting ${ }^{\circ} \mathrm{C}-$ Estimated from Loggers & 21.1 & 2.5 & 21.3 & 195 & $20.8,21.5$ \\
Thermostat Setting ${ }^{\circ} \mathrm{C}-$ Respondent Reported & 19.0 & 3.0 & 20.0 & 164 & $18.6,19.5$ \\
CH Hours per day estimated active on weekdays & 8.2 & 1.5 & 8.2 & 196 & $8.0,8.4$ \\
CH Hours per day estimated active on weekends & 8.4 & 1.5 & 8.4 & 196 & $8.2,8.6$ \\
CH Hours per day estimated active average over week & 8.3 & 1.5 & 8.3 & 196 & $8.1,8.5$ \\
CH Hours per day reported used on weekdays & 9.4 & 5.4 & 8.0 & 344 & $8.9,10.0$ \\
CH Hours per day reported used on weekends & 9.8 & 5.4 & 8.5 & 344 & $9.2,10.4$ \\
CH hours per day reported used average over week & 9.5 & 5.4 & 8.0 & 343 & $9.0,10.1$ \\
\hline
\end{tabular}




\section{Table 3 Thermostat settings estimated and reported}

Table 3 Thermostat settings estimated and reported

\begin{tabular}{|c|c|c|c|c|c|}
\hline \multicolumn{3}{|c|}{ Thermostat Setting ${ }^{\circ} \mathrm{C}$ Estimated } & \multicolumn{3}{|c|}{ Thermostat Setting ${ }^{\circ} \mathrm{C}$ Reported } \\
\hline Values & $\%$ & Cumulative \% & Values & $\%$ & Cumulative \% \\
\hline $13.1-17.9$ & 8.7 & 8.7 & $10-17$ & 26.8 & 26.8 \\
\hline $18.0-18.9$ & 7.7 & 16.4 & 18 & 12.8 & 39.6 \\
\hline $19.0-19.9$ & 13.9 & 30.3 & 19 & 6.1 & 45.7 \\
\hline $20.0-20.9$ & 17.4 & 47.7 & 20 & 29.9 & 75.6 \\
\hline $21.0-21.9$ & 12.3 & 60.0 & 21 & 7.3 & 82.9 \\
\hline $22.0-22.9$ & 16.9 & 76.9 & 22 & 8.5 & 91.5 \\
\hline $23.0-23.9$ & 11.8 & 88.7 & 23 & 1.2 & 92.7 \\
\hline $24.0-27.3$ & 11.3 & 100 & $24-26$ & 7.3 & 100 \\
\hline
\end{tabular}




\section{Table 4 Central heating thermostat settings estimated and reported}

\section{- by building demographics}

Table 4 Central heating thermostat settings estimated and reported - by building demographics

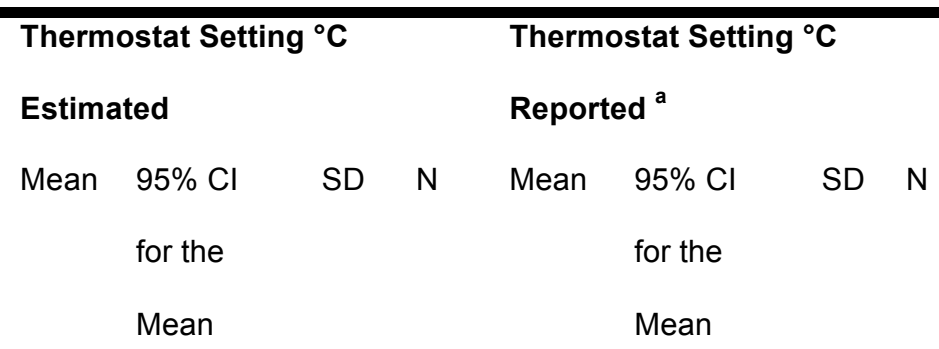

\begin{tabular}{llllllllll}
\hline Accommodation Type $^{\mathbf{b}}$ & & & & & & & & & \\
End Terrace & 21.2 & $19.6,22.7$ & 3.2 & 19 & 19.2 & $17.5,20.8$ & 2.7 & 13 \\
Mid Terrace & 21.0 & $20.1,21.9$ & 2.3 & 29 & 19.3 & $18.1,20.4$ & 2.6 & 22 \\
Semi Detached & 21.6 & $21.0,22.3$ & 2.3 & 55 & 18.8 & $17.9,19.7$ & 3.3 & 49 \\
Detached & 21.0 & $20.4,21.6$ & 2.5 & 70 & 19.3 & $18.6,20.1$ & 2.9 & 59 \\
Purpose Built Flat & 21.6 & $20.3,23.0$ & 2.4 & 14 & 18.5 & $15.9,21.1$ & 4.3 & 13 \\
$F$ & 0.71 & & & & 0.33 & & &
\end{tabular}

Accommodation Year

Built

Pre 1919

1919 to 1944

1945 to 1964

1965 to 1980

1981 to 1990

Post 1990

F

$p$

Roof Insulation

$>100 \mathrm{~mm} ; \mathrm{U}<0.40$

$\begin{array}{llllllll}\mathbf{2 0 . 1} & 19.1,21.0 & 2.3 & 25 & 18.9 & 17.7,20.2 & 2.4 & 17 \\ 21.3 & 20.4,22.2 & 2.8 & 36 & 18.8 & 17.4,20.3 & 3.4 & 25 \\ \mathbf{2 1 . 9} & 21.3,22.5 & 1.9 & 45 & 19.8 & 18.7,21.0 & 3.2 & 33 \\ 21.0 & 20.3,21.8 & 2.8 & 51 & 19.1 & 18.0,20.2 & 3.3 & 38 \\ 20.8 & 19.6,22.0 & 2.8 & 23 & 18.6 & 17.6,19.5 & 2.2 & 24 \\ 20.8 & 19.5,22.1 & 2.3 & 14 & 18.5 & 17.3,19.8 & 3.1 & 26 \\ 1.94 & & & & 0.71 & & & \\ \mathbf{0 . 0 9} & & & & & & & \end{array}$

$\begin{array}{llllllll}21.2 & 20.5,21.8 & 2.3 & 55 & 19.1 & 18.3,19.8 & 2.9 & 54\end{array}$ 


\begin{tabular}{|c|c|c|c|c|c|c|c|c|}
\hline & \multicolumn{3}{|c|}{$\begin{array}{l}\text { Thermostat Setting }{ }^{\circ} \mathrm{C} \\
\text { Estimated }\end{array}$} & & \multicolumn{3}{|c|}{$\begin{array}{l}\text { Thermostat Setting }{ }^{\circ} \mathrm{C} \\
\text { Reported }^{\text {a }}\end{array}$} & \multirow[b]{2}{*}{$N$} \\
\hline & Mean & $\begin{array}{l}95 \% \mathrm{Cl} \\
\text { for the } \\
\text { Mean }\end{array}$ & $\mathrm{SD}$ & $\mathrm{N}$ & Mean & $\begin{array}{l}95 \% \mathrm{Cl} \\
\text { for the } \\
\text { Mean }\end{array}$ & SD & \\
\hline$=100 \mathrm{~mm} ; U=0.40$ & 21.1 & $20.4,21.8$ & 2.5 & 58 & 19.2 & $18.6,19.8$ & 2.0 & 44 \\
\hline$<100 \mathrm{~mm} ; \mathrm{U}>0.40$ & 21.5 & $20.8,22.2$ & 2.5 & 54 & 19.0 & $17.9,20.2$ & 3.9 & 46 \\
\hline$F$ & 0.47 & & & & 0.3 & & & \\
\hline$p$ & 0.62 & & & & 0.97 & & & \\
\hline
\end{tabular}

Windows double-glazed

$\begin{array}{lrrrrrrrr}\text { All } & \mathbf{2 1 . 5} & 21.1,21.8 & 2.4 & 150 & 19.1 & 18.6,19.6 & 3.0 & 133 \\ \text { Some } & \mathbf{1 9 . 8} & 18.8,20.8 & 2.5 & 27 & 18.7 & 16.9,20.5 & 3.7 & 19 \\ \text { None } & 20.3 & 18.7,21.9 & 3.2 & 18 & 19.3 & 17.6,20.9 & 2.6 & 12 \\ F & 6.13 & & & & 0.16 & & \\ p & \mathbf{0 . 0 0 3} & & & & & & & \\ & & & & & & & & \end{array}$

Windows draught-proofed

$\begin{array}{lrrrrrrrr}\text { All } & \mathbf{2 1 . 4} & 21.0,21.7 & 2.4 & 162 & 19.0 & 18.5,19.5 & 3.0 & 140 \\ \text { Some } & \mathbf{1 9 . 6} & 18.4,20.9 & 3.0 & 24 & 18.6 & 16.9,20.4 & 3.3 & 17 \\ \text { None } & 20.5 & 18.1,22.9 & 3.1 & 9 & 19.9 & 17.3,22.4 & 2.8 & 7 \\ F & 5.37 & & & & 0.40 & & & \\ p & \mathbf{0 . 0 0 5} & & & & & & & \\ & & & & & & & & \end{array}$

Temperature Control

$\begin{array}{lllll}\text { Roomstat } & 21.2 & 20.8,21.7 & 2.4 & 117 \\ \text { TRV }^{\text {c }} \text { only } & 21.3 & 20.5,22.2 & 2.6 & 39 \\ \text { None mentioned } & 20.6 & 19.6,21.5 & 2.9 & 39 \\ F & 1.14 & & & \\ p & 0.32 & & \end{array}$

Roomstat Location ${ }^{\text {d }}$

$\begin{array}{lllllllll}\text { Main Living Room } & 21.3 & 20.4,22.1 & 2.0 & 22 & 18.7 & 17.5,19.8 & 3.4 & 37\end{array}$ 


\begin{tabular}{|c|c|c|c|c|c|c|c|c|}
\hline & \multicolumn{3}{|c|}{$\begin{array}{l}\text { Thermostat Setting }{ }^{\circ} \mathrm{C} \\
\text { Estimated }\end{array}$} & & \multicolumn{3}{|c|}{$\begin{array}{l}\text { Thermostat Setting }{ }^{\circ} \mathrm{C} \\
\text { Reported }^{\mathrm{a}}\end{array}$} & \multirow[b]{2}{*}{$\mathrm{N}$} \\
\hline & Mean & $\begin{array}{l}95 \% \mathrm{Cl} \\
\text { for the } \\
\text { Mean }\end{array}$ & SD & $\mathrm{N}$ & Mean & $\begin{array}{l}95 \% \mathrm{Cl} \\
\text { for the } \\
\text { Mean }\end{array}$ & SD & \\
\hline Hall & 21.1 & $20.4,21.7$ & 2.6 & 63 & 19.1 & $18.6,19.7$ & 3.0 & 102 \\
\hline$t$ & 0.32 & & & & -0.82 & & & \\
\hline$p$ & 0.75 & & & & 0.41 & & & \\
\hline
\end{tabular}




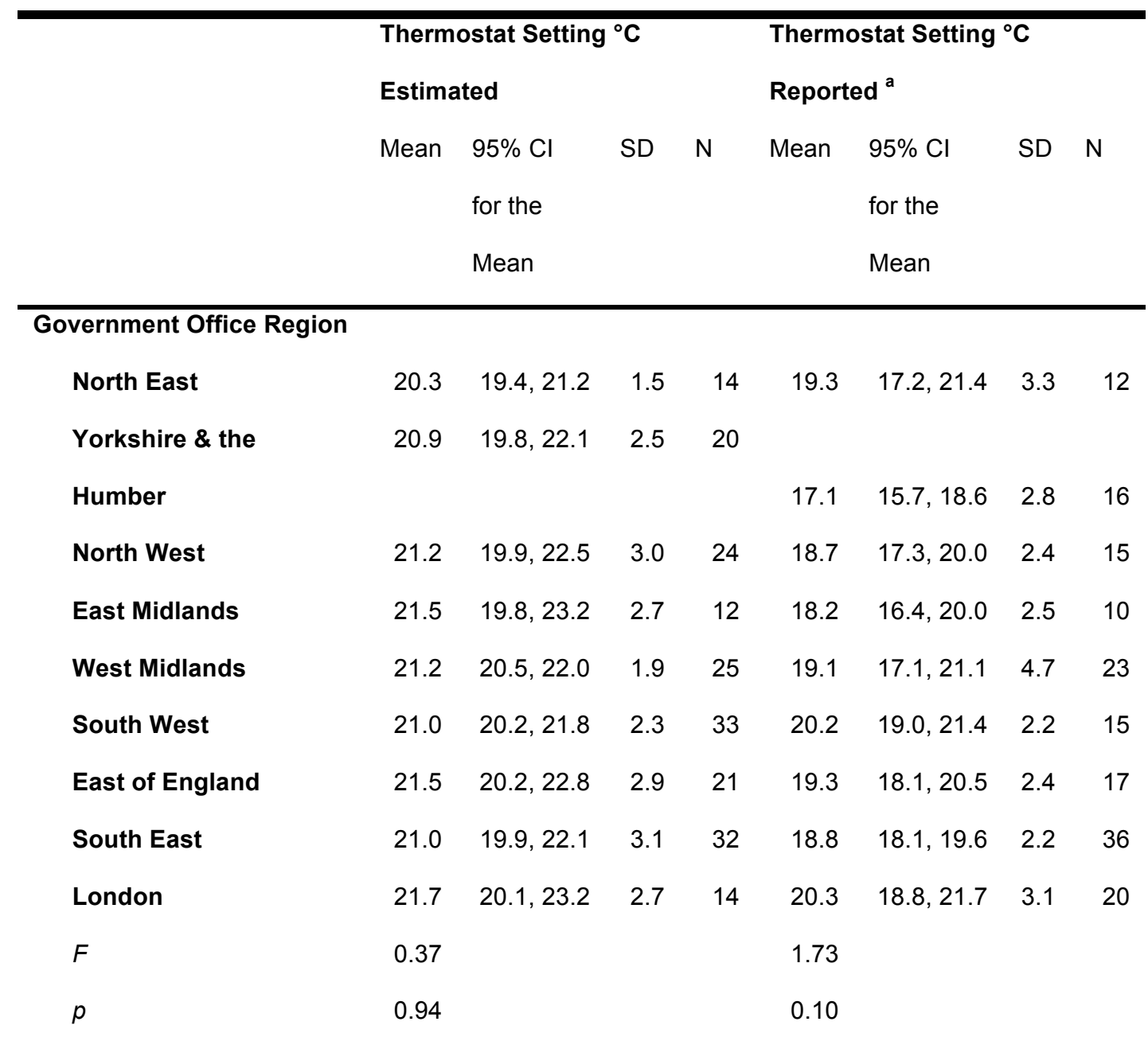

Note: $F$-statistics are for one-way ANOVAs for unrelated samples. Where the $F$-statistic is statistically significant to the level of $p<0.1$, Scheffé post-hoc multiple comparisons were computed and the most statistically significant mean difference is highlighted. $T$-tests were for the equality of two means and equal variances were assumed.

${ }^{\mathrm{a}}$ Includes only thermostat settings above $9^{\circ} \mathrm{C}$ and below $30^{\circ} \mathrm{C}$.

${ }^{\mathrm{b}}$ Converted flats and other accommodation excluded from this analysis due to insufficient numbers.

${ }^{\mathrm{c}} \mathrm{A}$ TRV is a thermostatic radiator valve.

${ }^{\mathrm{d}}$ Roomstats located in rooms other than the main living room or hall are excluded from this analysis due to insufficient numbers. 
Table 5 Central heating estimated active hours per day and reported hours on per day - by building demographics

Table 5 Central heating estimated active hours per day and reported hours on per day - by building demographics

\begin{tabular}{|c|c|c|c|c|c|c|c|c|}
\hline & \multicolumn{4}{|c|}{$\begin{array}{l}\text { Central Heating Active } \\
\text { Estimated Hours Per Day }\end{array}$} & \multicolumn{4}{|c|}{$\begin{array}{c}\text { Central Heating On } \\
\text { Reported Hours Per Day }\end{array}$} \\
\hline & Mean & $\begin{array}{l}95 \% \mathrm{Cl} \\
\text { for the } \\
\text { Mean }\end{array}$ & SD & $\mathrm{N}$ & Mean & $\begin{array}{l}95 \% \mathrm{Cl} \\
\text { for the } \\
\text { Mean }\end{array}$ & SD & $\mathrm{N}$ \\
\hline \multicolumn{9}{|l|}{ Accommodation Type ${ }^{\mathrm{a}}$} \\
\hline End Terrace & 8.3 & $7.5,9.1$ & 1.7 & 20 & 8.8 & $6.6,11.0$ & 6.1 & 33 \\
\hline Mid Terrace & 7.7 & $7.1,8.2$ & 1.4 & 29 & 8.3 & $6.7,9.8$ & 5.4 & 52 \\
\hline Semi Detached & 8.3 & $8.0,8.7$ & 1.4 & 55 & 9.8 & $8.8,10.8$ & 5.2 & 103 \\
\hline Detached & 8.7 & $8.4,9.1$ & 1.4 & 70 & 10.9 & $9.8,11.9$ & 5.3 & 106 \\
\hline Purpose Built Flat & 7.6 & $6.8,8.5$ & 1.5 & 14 & 8.8 & $6.6,11.0$ & 6.0 & 32 \\
\hline$F$ & 3.69 & & & & 2.58 & & & \\
\hline$p$ & 0.007 & & & & 0.04 & & & \\
\hline
\end{tabular}

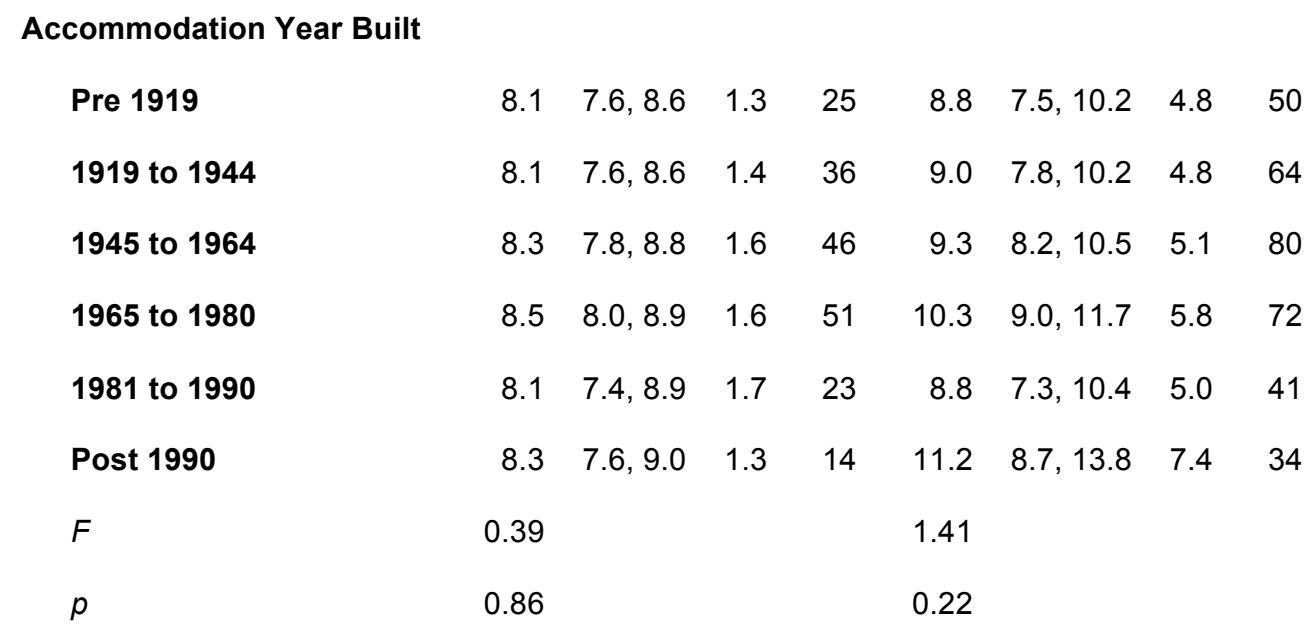

Roof Insulation

\begin{tabular}{lllllllll}
$>100 \mathrm{~mm} ; \mathbf{U}<\mathbf{0 . 4 0}$ & 8.2 & $7.9,8.6$ & 1.4 & 55 & 10.0 & $8.8,11.2$ & 6.0 & 98 \\
$=\mathbf{1 0 0 m m} ; \mathbf{U}=\mathbf{0 . 4 0}$ & 8.6 & $8.2,8.9$ & 1.5 & 58 & 9.4 & $8.4,10.5$ & 4.8 & 85 \\
\hline
\end{tabular}




\begin{tabular}{|c|c|c|c|c|c|c|c|c|}
\hline & \multicolumn{4}{|c|}{$\begin{array}{l}\text { Central Heating Active } \\
\text { Estimated Hours Per Day }\end{array}$} & \multicolumn{4}{|c|}{$\begin{array}{l}\text { Central Heating On } \\
\text { Reported Hours Per Day }\end{array}$} \\
\hline & Mean & $\begin{array}{l}95 \% \mathrm{Cl} \\
\text { for the } \\
\text { Mean }\end{array}$ & SD & $\mathrm{N}$ & Mean & $\begin{array}{l}95 \% \mathrm{Cl} \\
\text { for the } \\
\text { Mean }\end{array}$ & $\mathrm{SD}$ & $\mathrm{N}$ \\
\hline$<100 \mathrm{~mm} ; \mathrm{U}>0.40$ & 8.3 & $7.9,8.7$ & 1.5 & 55 & 9.3 & $8.3,10.3$ & 5.1 & 105 \\
\hline$F$ & 0.70 & & & & 0.49 & & & \\
\hline$p$ & 0.50 & & & & 0.61 & & & \\
\hline
\end{tabular}

Windows double-glazed

\begin{tabular}{|c|c|c|c|c|c|c|c|}
\hline All & 8.4 & $8.1,8.6$ & 1.5 & 151 & 9.7 & $9.0,10.4$ & 5.7 \\
\hline Some & 8.2 & $7.6,8.8$ & 1.5 & 27 & 9.2 & $7.8,10.5$ & 4.4 \\
\hline None & 7.7 & $6.8,8.6$ & 1.8 & 18 & 9.0 & $7.4,10.7$ & 5.0 \\
\hline$F$ & 1.58 & & & & 0.36 & & \\
\hline$p$ & 0.21 & & & & 0.70 & & \\
\hline
\end{tabular}

Windows draught-proofed

\begin{tabular}{|c|c|c|c|c|c|c|c|}
\hline All & 8.3 & $8.1,8.6$ & 1.5 & 163 & 9.7 & $9.0,10.3$ & 5.7 \\
\hline Some & 8.2 & $7.5,8.8$ & 1.5 & 24 & 8.8 & $7.4,10.1$ & 4.3 \\
\hline None & 7.3 & $5.9,8.6$ & 1.8 & 9 & 9.8 & $7.6,11.9$ & 5.2 \\
\hline$F$ & 2.30 & & & & 0.53 & & \\
\hline$p$ & 0.10 & & & & 0.59 & & \\
\hline
\end{tabular}

Time Control

$\begin{array}{lrrrrrrrr}\text { Timer/Controller } & 8.3 & 8.1,8.5 & 1.5 & 172 & 9.4 & 8.8,10.0 & 5.1 & 297 \\ \text { None Mentioned } & 8.1 & 7.4,8.7 & 1.6 & 24 & 10.7 & 8.6,12.9 & 7.1 & 45 \\ t & 0.74 & & & & -1.23 & & & \\ p & 0.46 & & & & & & & \\ t & & & & & & & & \end{array}$

Timer or Manual Operation

\begin{tabular}{lrrrrrrrr} 
Timer/ Controller & 8.4 & $8.2,8.6$ & 1.4 & 134 & 9.2 & $8.7,9.8$ & 4.5 & 226 \\
Manual Operation & 8.0 & $7.6,8.4$ & 1.7 & 62 & 10.2 & $8.9,11.4$ & 6.8 & 116 \\
$t$ & 1.73 & & & & -1.31 & & & \\
\hline
\end{tabular}




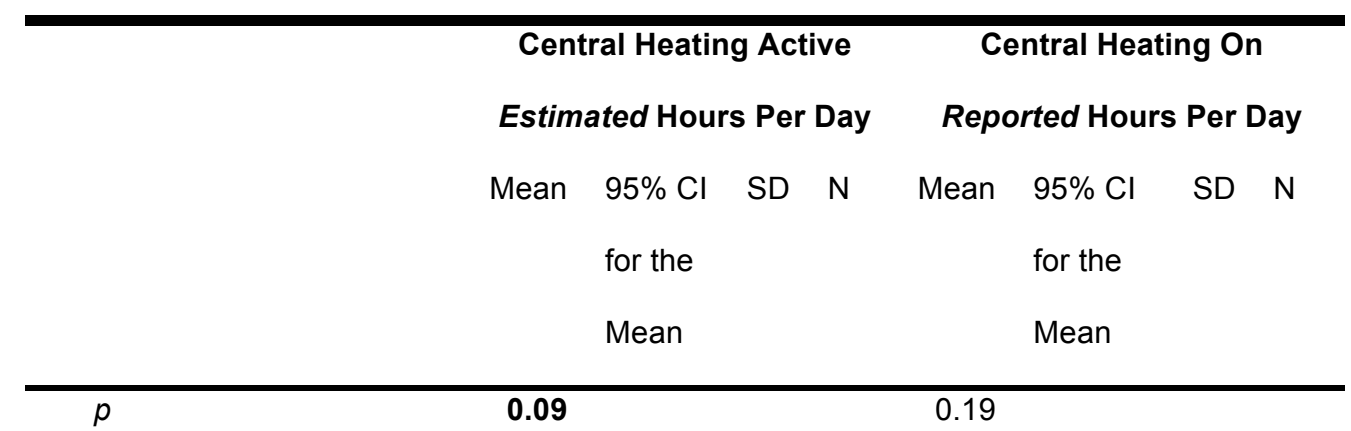

$\begin{array}{lcccccccc}\text { Government Office Region } & & & & & & & \\ \text { North East } & 7.7 & 6.8,8.6 & 1.6 & 14 & 8.4 & 6.1,10.7 & 4.1 & 15 \\ \text { Yorkshire \& the Humber } & 8.1 & 7.6,8.7 & 1.2 & 20 & 9.2 & 7.4,11.0 & 5.3 & 36 \\ \text { North West } & 8.6 & 8.0,9.1 & 1.3 & 24 & 9.5 & 7.8,11.1 & 5.8 & 50 \\ \text { East Midlands } & 8.2 & 6.9,9.4 & 2.0 & 12 & 9.1 & 6.8,11.4 & 5.7 & 26 \\ \text { West Midlands } & 8.7 & 8.2,9.1 & 1.2 & 26 & 10.7 & 9.0,12.4 & 5.3 & 40 \\ \text { South West } & 8.3 & 7.7,8.9 & 1.7 & 33 & 8.2 & 7.0,9.5 & 4.3 & 48 \\ \text { East of England } & 8.7 & 8.0,9.4 & 1.5 & 21 & 11.2 & 9.1,13.3 & 5.6 & 30 \\ \text { South East } & 8.2 & 7.6,8.8 & 1.6 & 32 & \mathbf{1 0 . 8} & 9.1,12.4 & 6.2 & 58 \\ \text { London } & 7.5 & 6.8,8.3 & 1.4 & 14 & \mathbf{8 . 0} & 6.5,9.4 & 4.6 & 40 \\ F & 1.30 & & & & 1.90 & & & \\ P & 0.25 & & & & \mathbf{0 . 0 6} & & & \end{array}$

Note: $F$-statistics are for one-way ANOVAs for unrelated samples. Where the $F$-statistic is statistically significant to the level of $p=0.1$, Scheffé post-hoc multiple comparisons were computed and the most statistically significant mean difference is highlighted. $T$-tests are for the equality of two means and equal variances were assumed for estimated active hours per day, but not assumed for reported hours per day.

${ }^{\text {a }}$ Converted flats and other accommodation excluded from this analysis due to insufficient numbers. 
Figure 1 Map of local authorities sampled in the survey

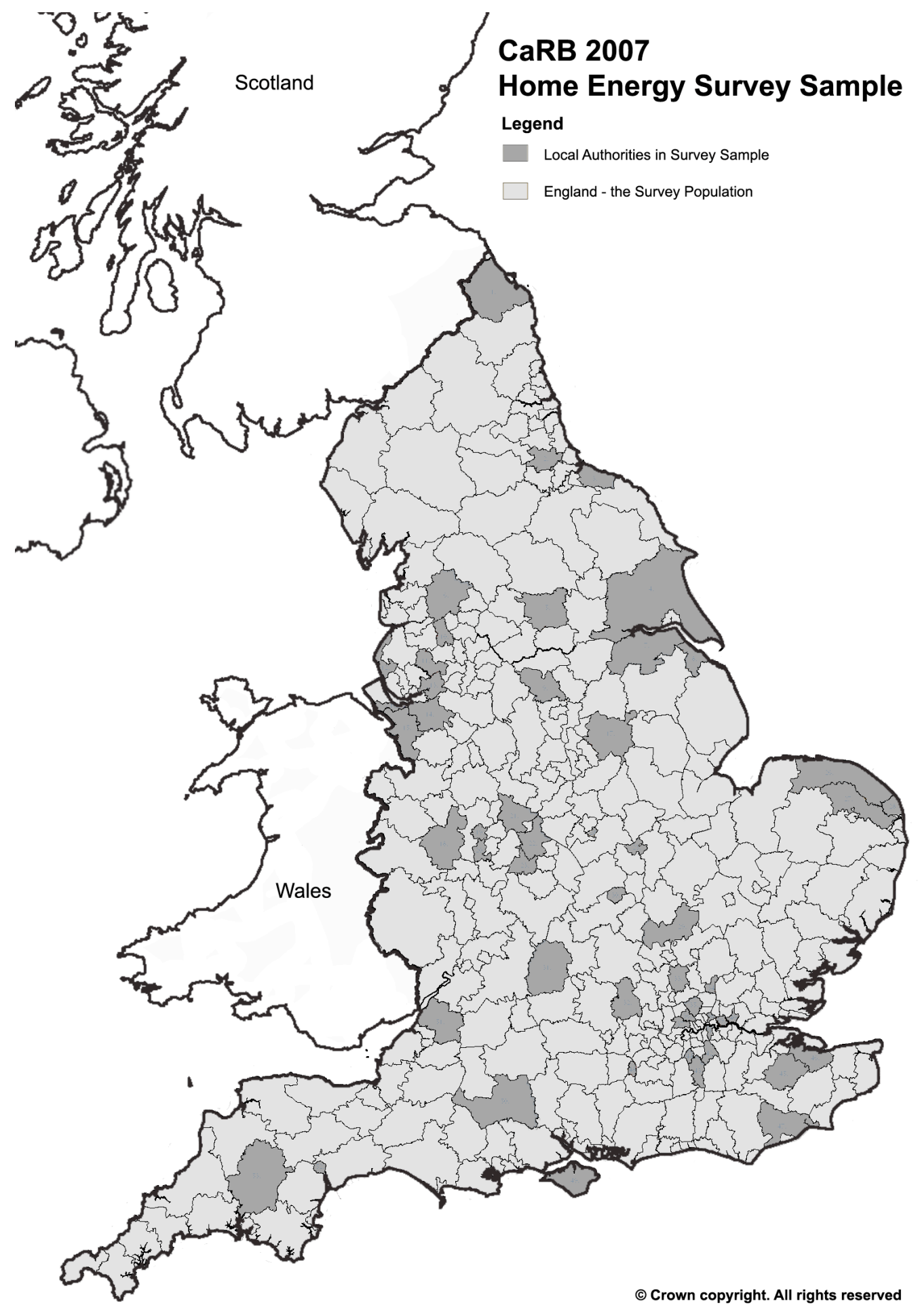

Figure 1 Map of local authorities sampled in the survey [TIFF version also provided] 
Figure 2 Living room, bedroom and external air temperatures, recorded at 45 minute intervals, for a single house on Monday 10th December 2007

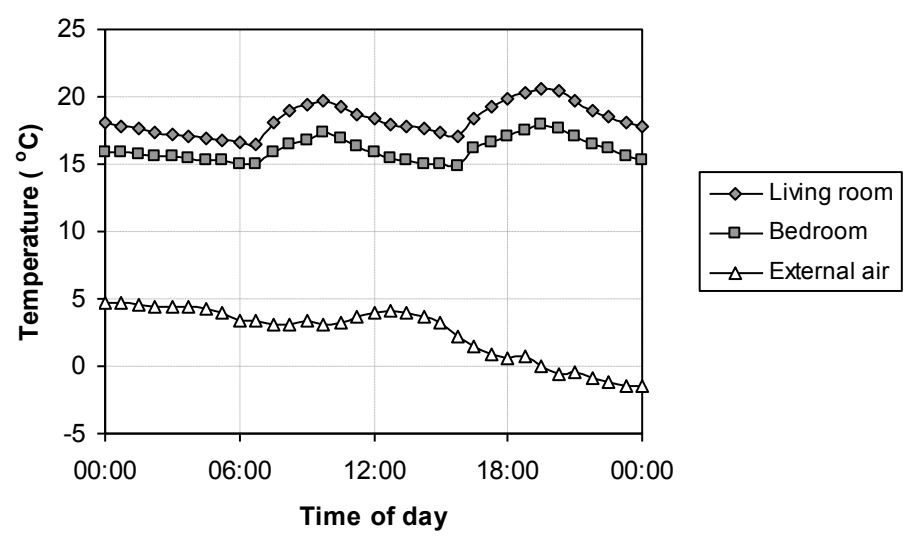

Figure 2 Living room, bedroom and external air temperatures, recorded at 45 minute intervals, for a single house on Monday 10th December 2007 
Figure 3 Thermostat settings - estimated and reported

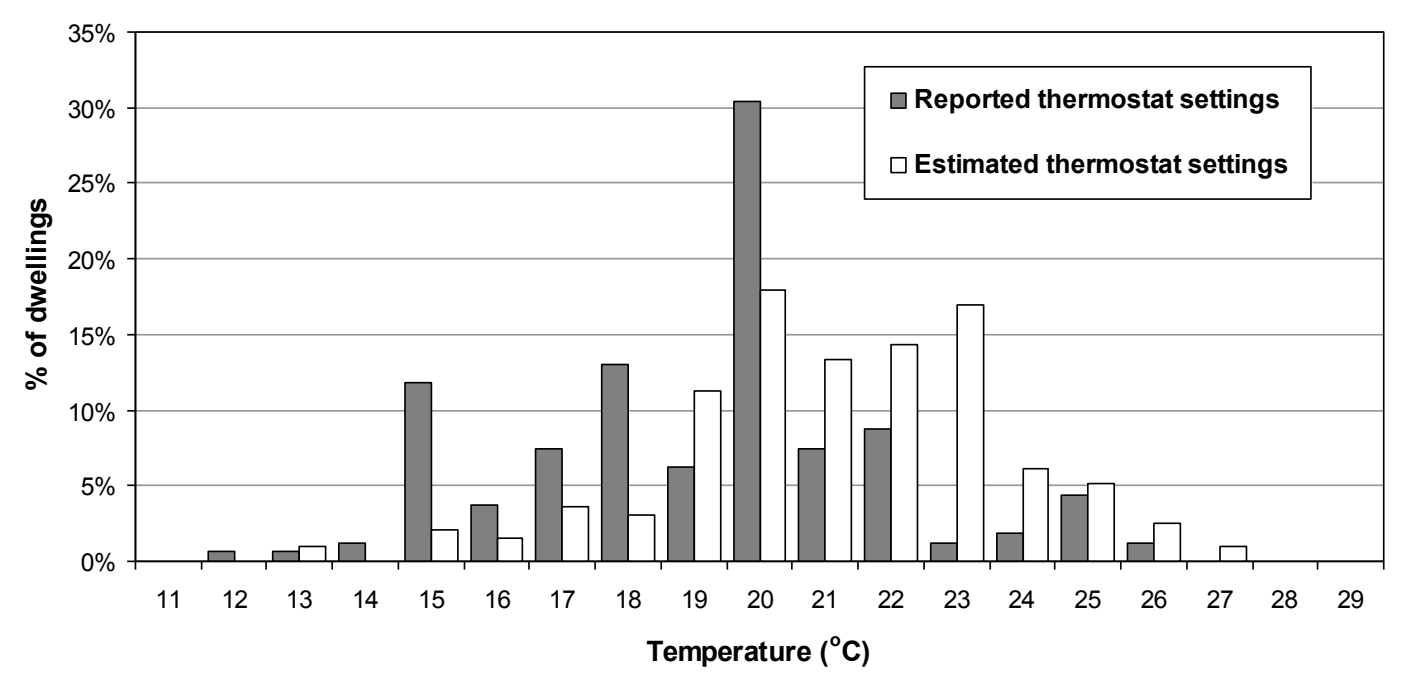

Figure 3 Thermostat settings - estimated and reported 
Figure 4 Central heating hours - reported on-duty and estimated active

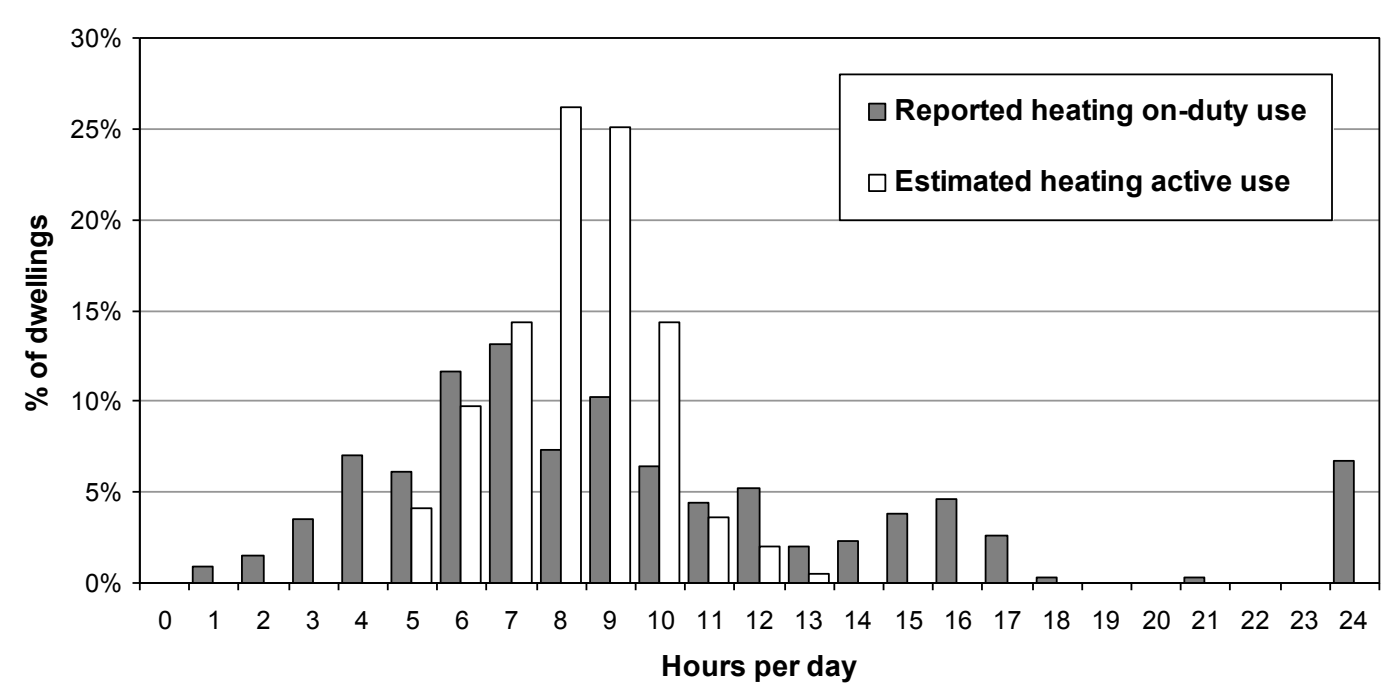

Figure 4 Central heating hours - reported on-duty and estimated active 
Figure 5 Thermostat settings - reported vs. estimated

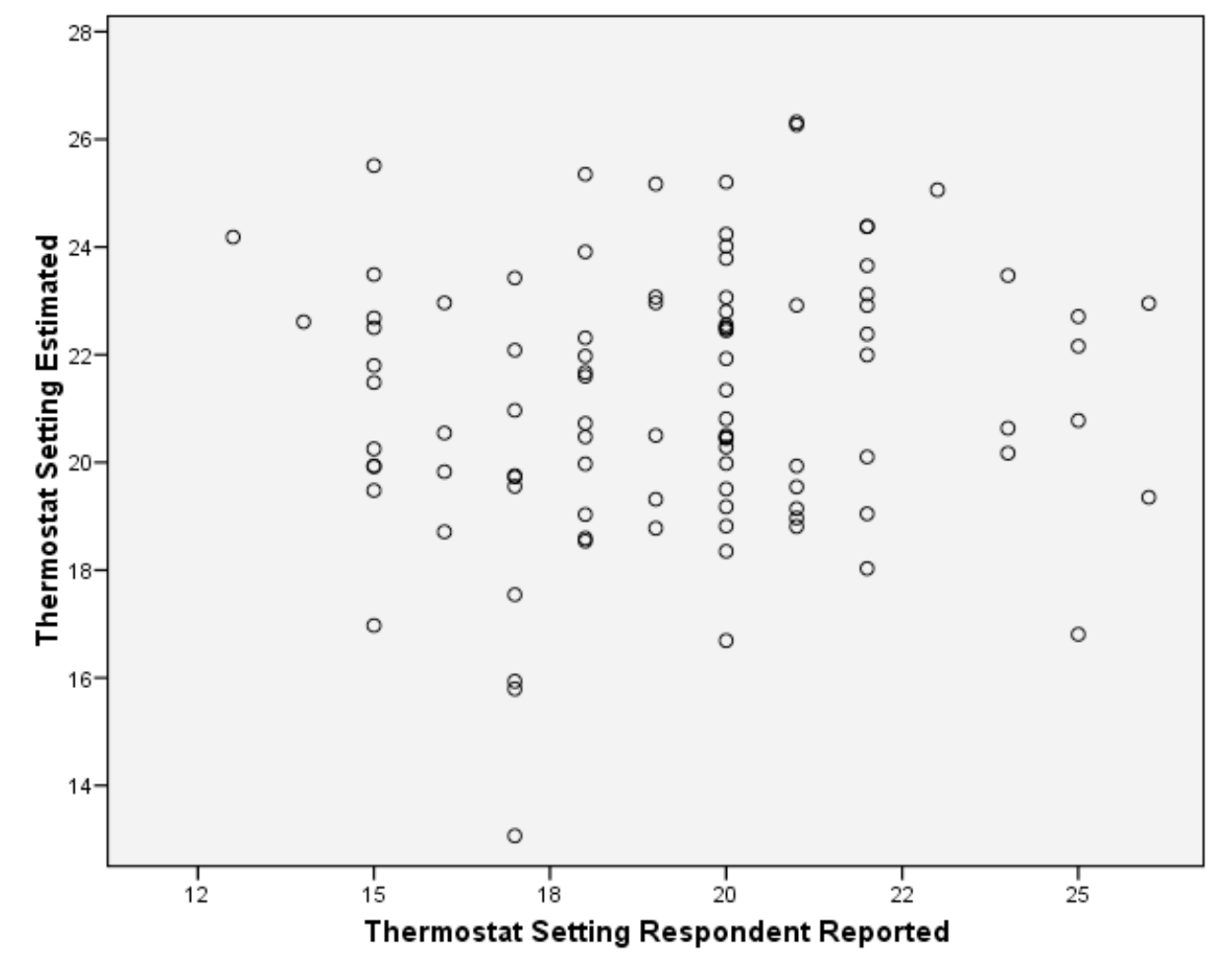

Figure 5 Thermostat settings - reported vs. estimated 


\section{Endnotes}

${ }^{\mathrm{i}}$ 'The proposed P1 target would result in energy use from conventional domestic heating and hot water systems falling to 400.5 TWh by 2020 . This would represent an energy saving of 14.5 TWh (0.8 MtC, 2.9 Mt CO2) over the Reference projections for 2020' (DEFRA 2008c, p. 4).

ii Postcode sectors were stratified by the percentage of households where the Census Household Reference Person was in National Statistics' Socio-economic Classification category 1 or 2 - i.e. employers in large organisations, managers, professionals, and higher technical and supervisory occupations

iii Outliers can have undue influence on parametric statistical tests, as well as on summary statistics (de Vaus 2002a). This is particularly problematic when comparing groups (e.g. those in different types of accommodation), especially if some groups have relatively small numbers of cases. Outliers are those cases disconnected from the remainder of the distribution, and 2-3 standard deviations from the mean.

${ }^{\text {iv }}$ Bungalows are all single-storey houses; all other houses have more than one floor. Terraced houses are in rows of at least three attached houses. A semi-detached house is attached to one other house. A converted flat is created when a house is converted into two or more flats, or a former non-residential building is converted into one or more flats.

${ }^{\mathrm{v}}$ Explanations of each of these controls were given as follows: A room thermostat or roomstat is used to choose the temperature the home should reach when the heating is on. It is usually found in the living room, dining room or hallway. Room thermostats may have a dial marked with the numbers $10,15,20,25$, and 30 , or they may be digital. A time clock, timer or programmer is used to set the times the heating comes on and goes off. Newer programmers 
are digital. A thermostatic radiator valve controls a single radiator and is used to keep a room at a different temperature to the rest of the home. Thermostatic radiator valves usually have a dial marked with a $*$ and numbers from 1 to 5 . A controller or programmable room thermostat is used to set the times the heating is on as well as the temperature the home should reach when the heating is on. They are digital. Illustrations of these controls were also provided. ${ }^{\mathrm{vi}}$ A multi-university, multi-disciplinary research project just under way - Carbon, Comfort and Control, led from University College London, is doing just this - applying a user-centred approach to developing new forms of heating control that $d o$ save energy. 